\title{
New pharmaceutical salts containing pyridoxine
}

\author{
Aleksandar Cvetkovski, Valeria Ferretti and Valerio Bertolasi
}

Acta Cryst. (2017). C73, 1064-1070

\section{H IUCr Journals CRYSTALLOGRAPHY JOURNALS ONLINE}

Copyright (C) International Union of Crystallography

Author(s) of this paper may load this reprint on their own web site or institutional repository provided that this cover page is retained. Republication of this article or its storage in electronic databases other than as specified above is not permitted without prior permission in writing from the IUCr.

For further information see http://journals.iucr.org/services/authorrights.html 
STRUCTURAL

CHEMISTRY

ISSN 2053-2296

Received 27 September 2017

Accepted 30 October 2017

Edited by M. Kubicki, Adam Mickiewicz University, Poland

Keywords: pharmaceutical cocrystals; active pharmaceutical ingredients; pyridoxine; crystal structure; SQUEEZE; vitamin B6 family.

CCDC references: 1582758; 1582757

Supporting information: this article has supporting information at journals.iucr.org/c

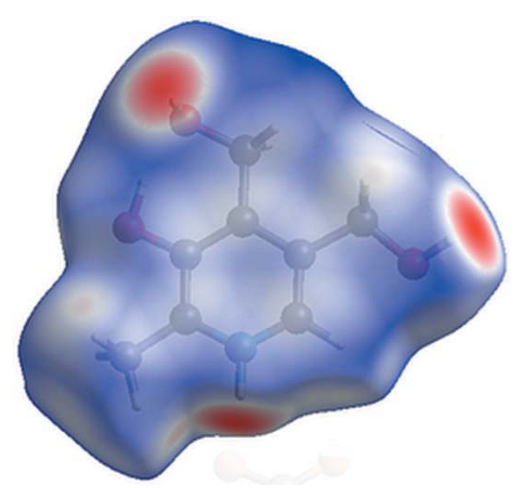

C 2017 International Union of Crystallography

\section{New pharmaceutical salts containing pyridoxine}

\author{
Aleksandar Cvetkovski, ${ }^{a}$ Valeria Ferretti ${ }^{\text {b* }}$ and Valerio Bertolasi ${ }^{b}$ \\ ${ }^{a}$ Faculty of Medical Sciences, University Goce Delcev, Krste Misirkov bb, 2000 PO 201, Štip, The Former Yugoslav \\ Republic of Macedonia, and ${ }^{\mathbf{b}}$ Department of Chemical and Pharmaceutical Sciences, University of Ferrara, via Fossato di \\ Mortara 17, Ferrara I-44121, Italy. *Correspondence e-mail: frt@unife.it
}

Two mixed crystals were obtained by crystallizing the active pharmaceutical ingredient pyridoxine [systematic name: 4,5-bis(hydroxymethyl)-2-methylpyridin-3-ol, PN] with (E)-3-(4-hydroxy-3-methoxyphenyl)prop-2-enoic acid (ferulic acid) and 4-hydroxy-3,5-dimethoxybenzoic acid (syringic acid). PN and the coformers crystallize in the form of pharmaceutical salts in a 1:1 stoichiometric ratio, namely 3-hydroxy-4,5-bis(hydroxymethyl)-2-methylpyridin-1-ium (E)-3(4-hydroxy-3-methoxyphenyl)prop-2-enoate, $\mathrm{C}_{8} \mathrm{H}_{12} \mathrm{NO}_{3}{ }^{+} \cdot \mathrm{C}_{9} \mathrm{H}_{9} \mathrm{O}_{5}{ }^{-}$, and 3-hydroxy-4,5-bis(hydroxymethyl)-2-methylpyridin-1-ium 4-hydroxy-3,5-dimethoxybenzoate monohydrate, $\mathrm{C}_{8} \mathrm{H}_{12} \mathrm{NO}_{3}{ }^{+} \cdot \mathrm{C}_{10} \mathrm{H}_{11} \mathrm{O}_{5}{ }^{-} \cdot \mathrm{H}_{2} \mathrm{O}$, the proton exchange between $\mathrm{PN}$ and the acidic partner being supported by the differences of the $\mathrm{p} K_{\mathrm{a}}$ values of the two components and by the $\mathrm{C}-\mathrm{O}$ bond lengths of the carboxylate groups. Besides complex hydrogen-bonding networks, $\pi-\pi$ interactions between aromatic moieties have been found to be important for the packing architecture in both crystals. Hirshfeld surface analysis was used to explore the intermolecular interactions in detail and compare them with the interactions found in similar pyridoxine/carboxylic acid salts.

\section{Introduction}

Multicomponent solids, designed by applying crystal engineering tools, have been, and continue to be, an active field of research in many areas dealing with functional materials. In particular, in the last decade, pharmaceutical chemists have expended a great deal of effort in synthesizing new crystalline phases, called pharmaceutical cocrystals (PCCs), where at least one component is an active pharmaceutical ingredient (API). PCCs are generally classified as mixed crystals in which a drug and other substances (coformers) present in neutral form cocrystallize in a stoichiometric ratio and are held together by intermolecular interactions, in such a way as to maintain unaltered the chemical structure of the API and hence its pharmacological profile. The increasing interest in PCCs is due to the fact that they display intermolecular motifs and crystal structures different from the pure API components and consequently can exhibit diverse specific physical properties, e.g. API dissolution rate and solubility (Nehm et al., 2006; Good \& Rodríguez-Hornedo, 2009; Goud et al., 2012), API pharmacokinetics (Cheney et al., 2010; Shan et al., 2014; Suresh et al., 2014, 2016), bioavailability (Bak et al., 2008; Jung et al., 2010) and permeability (Ferretti et al., 2015; Dalpiaz et al., 2017), efficiency and safety of the API native solid form, available in pharmaceutical formulations, and processability and stability of the sole crystalline form of PCC with a unique structure (Newman \& Wenslow, 2016; Battini et al., 2014; Trask, 2007) in comparison with all the solid forms in which the API may exist (Morissette et al., 2004; Almarsson et al., 2003). For these reasons, both the United States Food and 
Table 1

Experimental details.

(1)

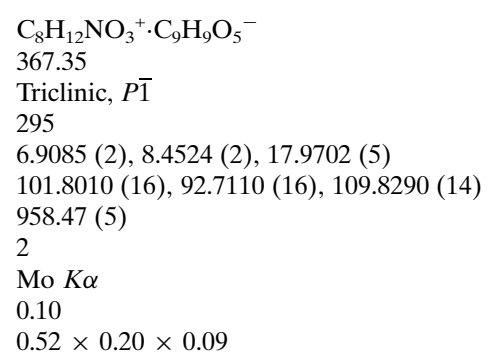

Nonius KappaCCD

$18203,4387,3191$

\subsection{5}

0.650
$0.053,0.167,1.06$
4387
256
0
$\mathrm{H}$ atoms treated by a mixture of independent and constrained refinement
$0.38,-0.27$

(2)

\author{
$\mathrm{C}_{8} \mathrm{H}_{12} \mathrm{NO}_{3}{ }^{+} \cdot \mathrm{C}_{10} \mathrm{H}_{11} \mathrm{O}_{5}{ }^{-} \cdot \mathrm{H}_{2} \mathrm{O}$ \\ 381.37 \\ Monoclinic, $P 2_{1}$ \\ 295 \\ 7.2440 (3), 17.1615 (5), 7.2706 (2) \\ 90, $98.806(2), 90$ \\ $893.21(5)$ \\ Mo $K \alpha$ \\ 0.11 \\ $0.35 \times 0.22 \times 0.13$ \\ Nonius KappaCCD \\ $11173,4578,3822$ \\ 0.034 \\ 0.703 \\ $0.040,0.108,1.07$ \\ 4578 \\ 272 \\ $\mathrm{H}$ atoms treated by a mixture of independent \\ and constrained refinement \\ $0.27,-0.18$ \\ Flack $x$ determined using 1452 quotients \\ $\left[\left(I^{+}\right)-\left(I^{-}\right)\right] /\left[\left(I^{+}\right)+\left(I^{-}\right)\right]$(Parsons et al., 2013) \\ $-0.4(4)$
}

Absolute structure parameter

$-$

Computer programs: COLLECT (Nonius, 1997), DENZO-SMN (Otwinowski \& Minor, 1997), SIR97 (Altomare et al., 1999), ORTEPIII (Burnett \& Johnson, 1996), MarvinSketch (ChemAxon, 2010), SHELXL2014 (Sheldrick, 2015) and WinGX (Farrugia, 2012).

Drug Administration (US FDA) and the European Medicines Agency (EMA) have delivered position documents about PCCs attesting the growing interest of their use in drug products and providing guidance to industry (FDA, 2016; EMA, 2014).<smiles>Cc1[nH+]cc(CO)c(CO)c1O</smiles><smiles>COc1cc(C(=O)[O-])cc(OC)c1O</smiles><smiles>Cc1[nH+]cc(CO)c(CO)c1O</smiles>

(1)<smiles>COc1cc(/C=C\C(=O)[O-])ccc1O</smiles>

(2)

In continuation of our interest in this field (Cvetkovski et al., 2016; Cvetkovski \& Ferretti, 2016), we have initiated a project on the synthesis of PCCs using the API pyridoxine and aromatic acids. Pyridoxine (henceforth referred to as $\mathrm{PN}$ ), in the form of an alcohol derivative of pyridine, is one of three members of the vitamin B6 family. The other two members, the aldehyde form pyridoxal and an amine form pyridoxamine, are known as pseudopyridoxines (Urbanski, 1949). These three forms are derivatives of $\beta$-hydroxypyridine; the presence of the pyridine ring is a structural characteristic shared with other vitamins of group $\mathrm{B}$, i.e. nicotinic acid and nicotinamide (niacin, vitamin B3), obtained by substituting the $\beta$-position with a carboxylic acid or amide group (Mooney et al., 2009). Due to the presence of a basic $\mathrm{N}$ atom $\left(\mathrm{PN} \mathrm{p} K_{\mathrm{a}}=\right.$ 5.1; Santos et al., 2010), pyridoxine can easily form salts with acidic molecules and, in fact, is mainly commercialized as pyridoxine hydrochloride.

The coformers selected for the present study were ferulic and syringic acids, belonging to the class of nutraceutic acids, whose $\mathrm{p} K_{\mathrm{a} 1}$ values are 4.27 (Erdemgil et al., 2007) and 3.86 (Chuysinuan et al., 2009), respectively. According to the socalled 'rule of three', when synthesizing a mixed crystal, a salt is expected if $\Delta \mathrm{p} K_{\mathrm{a}}\left[\mathrm{p} K_{\mathrm{a} \text { (base) }}-\mathrm{p} K_{\mathrm{a} \text { (acid) }}\right]$ is greater than 2 or 3 units, while the formation of a cocrystal is observed if $\Delta \mathrm{p} K_{\mathrm{a}}$ is less than 0 (Childs et al., 2007; Bhogala et al., 2005). $\Delta \mathrm{p} K_{\mathrm{a}}$ ranging between 0 and 2 or 3 is generally considered to indicate a salt-cocrystal continuum, so that it was not possible to predict a priori the formation of a salt or a cocrystal. The structures presented here for 3-hydroxy-4,5-bis(hydroxymethyl)-2-methylpyridin-1-ium 4-hydroxy-3,5-dimethoxyben- 


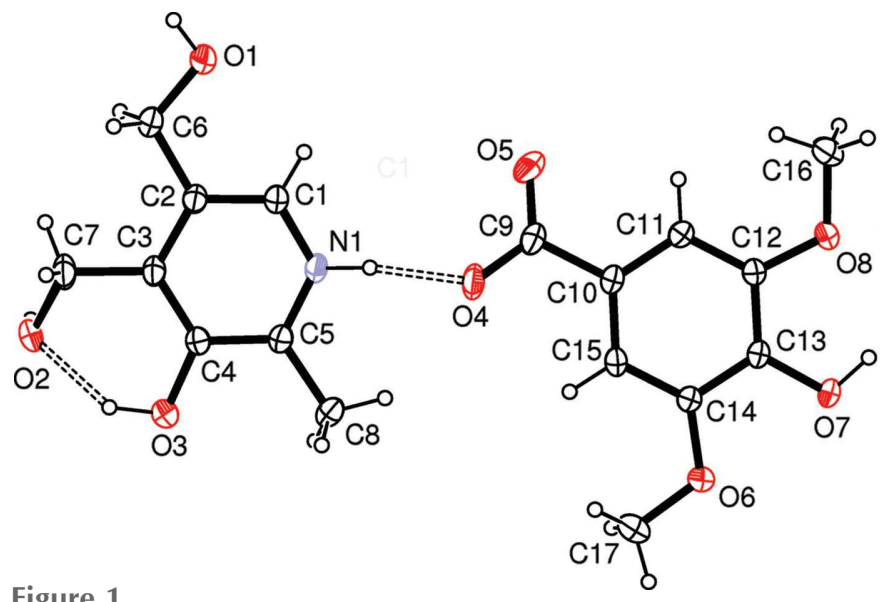

Figure 1

The molecular structure and atom-numbering scheme for (1), with displacement ellipsoids drawn at the $40 \%$ probability level. Hydrogen bonds are drawn as dashed lines.

zoate, (1), and 3-hydroxy-4,5-bis(hydroxymethyl)-2-methylpyridin-1-ium (E)-3-(4-hydroxy-3-methoxyphenyl)prop-2-enoate monohydrate, (2), are both molecular salts.

\section{Experimental}

\subsection{Synthesis and crystallization}

Pyridoxine, the other cocrystal formers and the solvents were purchased from Sigma-Aldrich and were used without further purification. All chemicals were of analytical or chromatographic grade.

2.1.1. Synthesis of pharmaceutical salt (1). The sediment of single crystals of PN-syringic acid (SYR) were prepared by slow evaporation from the isopropanol solution obtained after filtration of the slurry containing PN hydrochloride $(173 \mathrm{mg})$ neutralized with sodium hydroxide $(33.6 \mathrm{mg})$ (1:1 molar ratio) and syringic acid (166.7 mg) (PN neutral form-syringic acid in a 1:1 molar ratio) in isopropanol $(20 \mathrm{ml})$.

2.1.2. Synthesis of pharmaceutical salt (2). Colourless needle-shaped single crystals of the PN-ferulic acid (FER) salt were grown by slow evaporation from the clear solution obtained after filtration of the slurry prepared by mixing PN hydrochloride $(68.63 \mathrm{mg}$ ) and sodium hydroxide $(13.3 \mathrm{mg})$ (1:1 molar ratio) with feluric acid (64.8 mg) (PN neutral form/ base-ferulic acid in a 1:1 molar ratio) in a mixture of isopropanol and acetonitrile $(15 \mathrm{ml}, 1: 1 \mathrm{v} / \mathrm{v})$.

\subsection{Data collection and refinement}

Crystal data, data collection and structure refinement details are summarized in Table 1 . In salt (1), the electrondensity difference map showed some rather large broad peaks located in the centre of the unit cell. Attempts to identify the solvent molecules failed. Instead, a new set of $F^{2}(h k l)$ values with the contribution from solvent molecules withdrawn was obtained using the SQUEEZE procedure (Spek, 2015) implemented in PLATON (Spek, 2009). The potential solvent volume in the crystals is ca $124 \AA^{3}$ per unit-cell volume. In both structures, $\mathrm{H}$ atoms bound to $\mathrm{N}$ or $\mathrm{O}$ atoms were located in difference Fourier maps and refined isotropically, whereas $\mathrm{H}$ atoms bonded to $\mathrm{C}$ atoms were included at idealized positions and allowed to ride on their respective $\mathrm{C}$ atoms. The arene and methylene $\mathrm{H}$ atoms were constrained with $\mathrm{C}-\mathrm{H}=$ $0.93 \AA\left[U_{\text {iso }}(\mathrm{H})=1.2 U_{\text {eq }}(\mathrm{C})\right]$ and the methyl $\mathrm{H}$ atoms with $\mathrm{C}-\mathrm{H}=0.96 \AA\left[U_{\text {iso }}(\mathrm{H})=1.5 U_{\text {eq }}(\mathrm{C})\right]$.

\subsection{Hirshfeld surfaces and fingerprints evaluation}

Molecular Hirshfeld surfaces (Hirshfeld, 1977) and their 2D (two-dimensional) fingerprint plots (Spackman \& McKinnon, 2002; McKinnon et al., 2007) have been evaluated in order to gain additional insight into the network of intermolecular interactions in the crystals. The Hirshfeld surface represents the molecule when interacting with the crystal environment and the decomposition of this surface gives a 'molecular fingerprint', i.e. a 2D map indicating which intermolecular interactions are present and the relative area of the surface corresponding to each kind of interaction. The Hirshfeld surfaces and 2D fingerprint plots were generated using CrystalExplorer 3.0 (Wolff et al., 2012).

\section{Results and discussion}

The crystal of (1) (Fig. 1) is composed of cationic PN moieties, i.e. pyridoxinium, and syringate anions in a 1:1 stoichiometric ratio, as well as cocrystallized solvent molecules (vide supra), while the asymmetric unit of (2) (Fig. 2) is composed by one pyridoxinium cation, one ferulate anion and one water molecule in a 1:1:1 stoichiometric ratio. According to the 'rule of three', the $\Delta \mathrm{p} K_{\mathrm{a}}$ values of the $\mathrm{PN}$-ferulic acid (0.83) and $\mathrm{PN}-$ syringic acid (1.24) pairs are in the so-called 'salt-cocrystal continuum' region. In both structures, proton transfer from the carboxylic acid group to the basic pyridine $\mathrm{N}$ atom of the drug molecule is confirmed by (i) the delocalization of the $\mathrm{COO}^{-}$group, in terms of bond length and angle equalization $[\mathrm{C}-\mathrm{O}=1.235(2)$ and $1.275(2) \AA$ in (1), and 1.253 (3) and 1.267 (3) $\AA$ in (2); C-C $-\mathrm{O}=116.84(16)$ and $118.93(16)^{\circ}$ in (1) and $118.83(17)$ and $118.69(17)^{\circ}$ in (2)], and (ii) the values of the $\mathrm{C} 1-\mathrm{N} 1-\mathrm{C} 5$ bond angles, which are wider than those

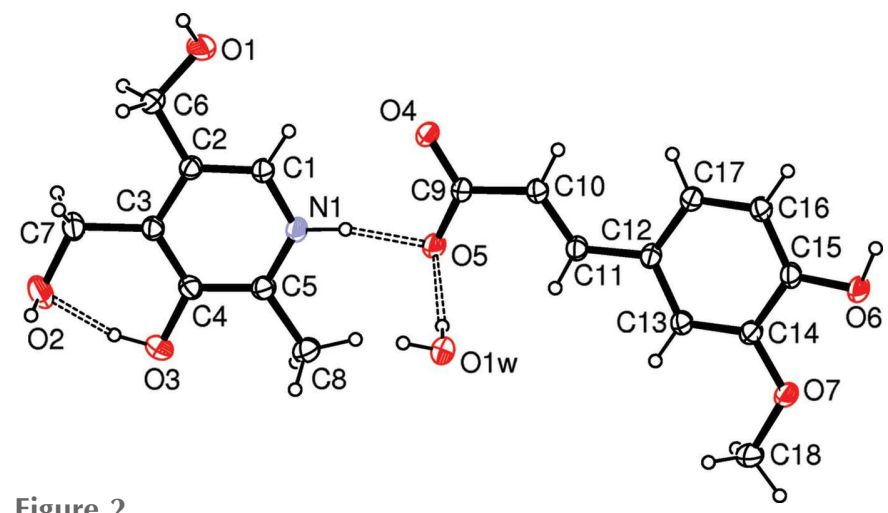

The molecular structure and atom-numbering scheme for (2), with displacement ellipsoids drawn at the $40 \%$ probability level. Hydrogen bonds are drawn as dashed lines. 
Table 2

Structural parameters for hydrogen-bond and $\pi-\pi$ interactions $\left(\AA{ }^{\circ},{ }^{\circ}\right.$ for (1) and (2).

$\mathrm{Cg}$ represents a ring centroid.

\begin{tabular}{|c|c|c|c|c|}
\hline$D-\mathrm{H} \cdots A$ & $D-\mathrm{H}$ & $D \cdots A$ & $\mathrm{H} \cdots A$ & $D-\mathrm{H} \cdot \cdot$ \\
\hline \multicolumn{5}{|l|}{ Cocrystal (1) } \\
\hline $\mathrm{N} 1-\mathrm{H} 1 \mathrm{~N} \cdots \mathrm{O} 4$ & $0.91(2)$ & $2.671(2)$ & $1.77(2)$ & $171(2)$ \\
\hline $\mathrm{O} 3-\mathrm{H} 3 \mathrm{O} \cdots \mathrm{O} 2$ & $0.95(4)$ & $2.663(2)$ & $1.83(4)$ & $144(3)$ \\
\hline $\mathrm{C} 8-\mathrm{H} 8 A \cdots \mathrm{O} 4$ & 0.96 & $3.308(2)$ & 2.52 & 139 \\
\hline $\mathrm{C} 1-\mathrm{H} 1 \cdots \mathrm{O} 1^{\mathrm{i}}$ & 0.93 & $3.359(2)$ & 2.47 & 158 \\
\hline $\mathrm{O} 1-\mathrm{H} 1 \mathrm{O} \cdots \mathrm{O}^{\mathrm{i}}$ & $0.85(3)$ & $2.663(2)$ & $1.83(3)$ & $166(3)$ \\
\hline $\mathrm{C} 6-\mathrm{H} 6 B \cdots \mathrm{O} 5^{\mathrm{ii}}$ & 0.97 & $3.576(3)$ & 2.64 & 161 \\
\hline $\mathrm{O} 2-\mathrm{H} 2 \mathrm{O} \cdots \mathrm{O} 4^{\mathrm{iii}}$ & $0.87(4)$ & $2.620(2)$ & $1.77(4)$ & $165(3)$ \\
\hline $\mathrm{O} 7-\mathrm{H} 7 \mathrm{O} \cdots \mathrm{O} 2^{\text {iv }}$ & $0.89(2)$ & $2.728(1)$ & $1.93(2)$ & $146(3)$ \\
\hline$C g(\mathrm{C} 10-\mathrm{C} 15) \cdots C g(\mathrm{~N} 1 / \mathrm{C} 1-\mathrm{C} 5)^{\mathrm{v}}$ & 3.552 & & & \\
\hline$C g(\mathrm{C} 10-\mathrm{C} 15) \cdots C g(\mathrm{~N} 1 / \mathrm{C} 1-\mathrm{C} 5)^{\mathrm{vi}}$ & 3.577 & & & \\
\hline \multicolumn{5}{|l|}{ Cocrystal (2) } \\
\hline $\mathrm{N} 1-\mathrm{H} 1 \mathrm{~N} \cdots \mathrm{O} 5$ & $0.93(4)$ & $2.641(2)$ & $1.73(5)$ & $166(4)$ \\
\hline $\mathrm{O} 3-\mathrm{H} 3 \mathrm{O} \cdots \mathrm{O} 2$ & $0.90(5)$ & $2.564(3)$ & $1.68(5)$ & $165(4)$ \\
\hline $\mathrm{O} 1 W-\mathrm{H} 2 W \cdots \mathrm{O} 5$ & $0.90(5)$ & $2.893(3)$ & $2.02(5)$ & $161(5)$ \\
\hline $\mathrm{C} 8-\mathrm{H} 8 A \cdots \mathrm{O} 5$ & 0.96 & $3.307(3)$ & 2.51 & 140 \\
\hline $\mathrm{O} 2-\mathrm{H} 2 \mathrm{O} \cdots \mathrm{O} 1^{\mathrm{vii}}$ & $0.91(6)$ & $2.747(3)$ & $1.84(6)$ & $171(5)$ \\
\hline $\mathrm{C} 8-\mathrm{H} 8 \mathrm{C} \cdots \mathrm{O} 4^{\mathrm{vii}}$ & 0.96 & $3.541(3)$ & 2.63 & 158 \\
\hline $\mathrm{C} 17-\mathrm{H} 17 \cdots \mathrm{O} 1 W^{\text {viii }}$ & 0.93 & $3.472(3)$ & 2.55 & 167 \\
\hline $\mathrm{O} 6-\mathrm{H} 6 \mathrm{O} \cdots \mathrm{O} 4^{\mathrm{ix}}$ & $0.94(4)$ & $2.545(2)$ & $1.62(4)$ & $166(4)$ \\
\hline $\mathrm{O} 1-\mathrm{H} 1 \mathrm{O} \cdots \mathrm{O} 1 W^{x}$ & $0.86(3)$ & $2.683(3)$ & $1.82(3)$ & $175(3)$ \\
\hline $\mathrm{O} 1 W-\mathrm{H} 1 W \cdots \mathrm{O} 6^{x}$ & $0.82(5)$ & $2.896(2)$ & $2.12(5)$ & $156(4)$ \\
\hline $\mathrm{O} 1 W-\mathrm{H} 1 W \cdots \mathrm{O}^{x}$ & $0.82(5)$ & $2.994(3)$ & $2.37(5)$ & $132(4)$ \\
\hline$C g(\mathrm{C} 12-\mathrm{C} 17) \cdots C g(\mathrm{~N} 1 / \mathrm{C} 1-\mathrm{C} 5)^{\mathrm{xi}}$ & 3.608 & & & \\
\hline$C g(\mathrm{C} 12-\mathrm{C} 17) \cdots C g(\mathrm{~N} 1 / \mathrm{C} 1-\mathrm{C} 5)^{\mathrm{xii}}$ & 3.671 & & & \\
\hline
\end{tabular}

Symmetry codes: (i) $-x,-y+1,-z$; (ii) $x+1, y+1, z$; (iii) $x, y+1, z$; (iv) $x-1, y-2, z$; (v) $x-1, y-1, z$; (vi) $x, y-1, z$; (vii) $x, y, z+1$; (viii) $x, y, z-1$; (ix) $-x+1, y+\frac{1}{2},-z+1$; (x) $-x+1, y-\frac{1}{2},-z+2$; (xi) $-x+1, y+\frac{1}{2},-z+2$; (xii) $-x+2, y+\frac{1}{2},-z+2$.

found in unprotonated pyridines [123.59 (14) ${ }^{\circ}$ in (1) and $123.26(18)^{\circ}$ in (2)].

The pyridoxinium cations are characterized by an intramolecular $\mathrm{O} 3-\mathrm{H} 3 \mathrm{O} \cdots \mathrm{O} 2$ hydrogen bond, while the protonated $\mathrm{N}$ atom forms a strong $\mathrm{N}-\mathrm{H}$. . O interaction with the coformer carboxylate group, whose short $\mathrm{N} \cdots \mathrm{O}$ distance is typical of charge-assisted hydrogen bonds (Table 2). Due to

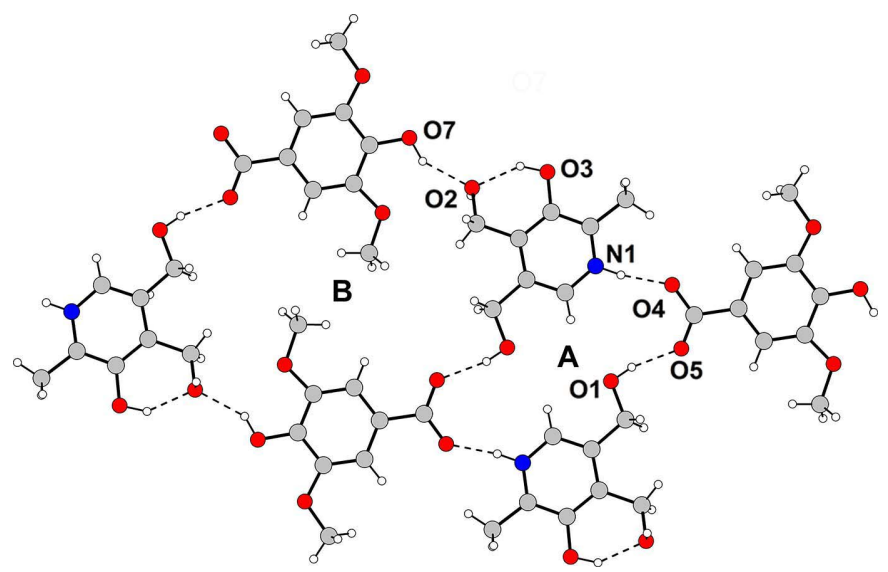

Figure 3

$R_{4}^{4}(20)$ (denoted $\mathbf{A}$ ) and $R_{4}^{4}(30)$ (denoted $\mathbf{B}$ ) rings formed in the $b c$ plane of (1). Hydrogen bonds are drawn as dashed lines. the plethora of good donor and acceptor groups, the hydrogen-bonding network appears to be rather complicated in both structures. In salt (1), the molecules are arranged in planar layers (in the $b c$ plane), forming $R_{4}^{4}(20)$ and $R_{4}^{4}(30)$ adjacent rings, marked as $\mathbf{A}$ and $\mathbf{B}$, respectively, in Fig. 3. These parallel layers are stacked along the $a$ direction and linked through $\mathrm{O} 2-\mathrm{H} 2 \mathrm{O} \cdots \mathrm{O} 4{ }^{\mathrm{iii}}$ hydogen bonds, with the possible involvement of the cocrystallized solvent molecules (vide supra). Indeed, the solvent is located in tunnels running along the $a$ direction, as shown in Fig. 4(a). Layers are also formed in salt (2); in this case, the role played by the cocrystallized water molecule in joining adjacent layers is evident, acting both as hydrogen-bonding donor (towards O6 and O7) and acceptor (from O1). The unit-cell contents, viewed along the $b$ axis, are shown in Fig. 5(a). It is worth noting that, besides hydrogen bonding, in both structures, $\pi-\pi$ interactions contribute to the robustness of the crystal (Table 2 and Figs. $4 b$ and $5 b)$. In both structures, drug/coformer mixed columns with heterogeneous interstack separations (André et al., 1997) are

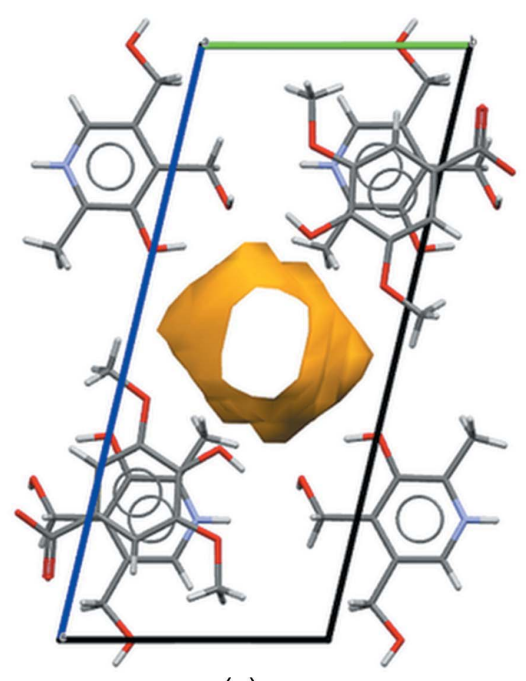

(a)

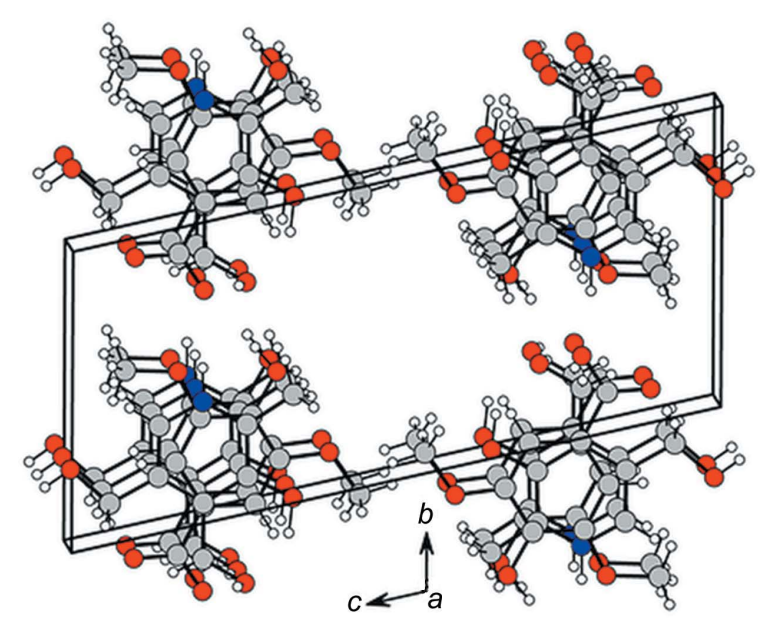

(b)

Figure 4

(a) The empty space in (1), viewed in projection along the $a$ axis. (b) The crystal projection showing the molecular stacking. 


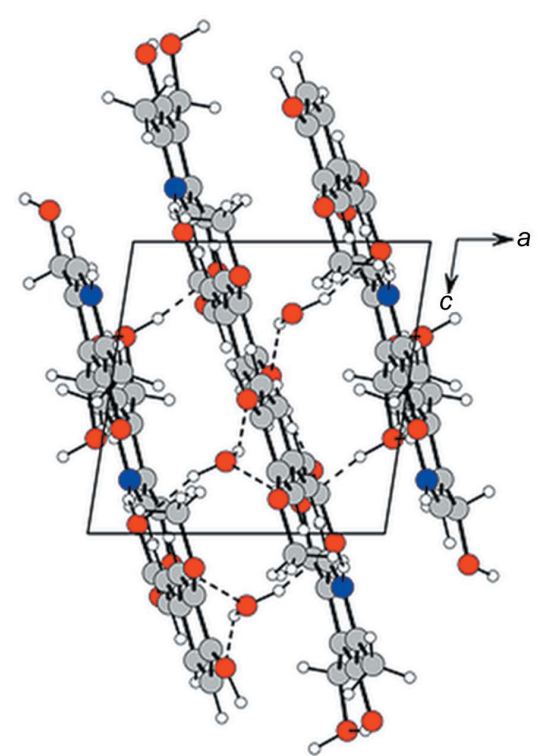

(a)

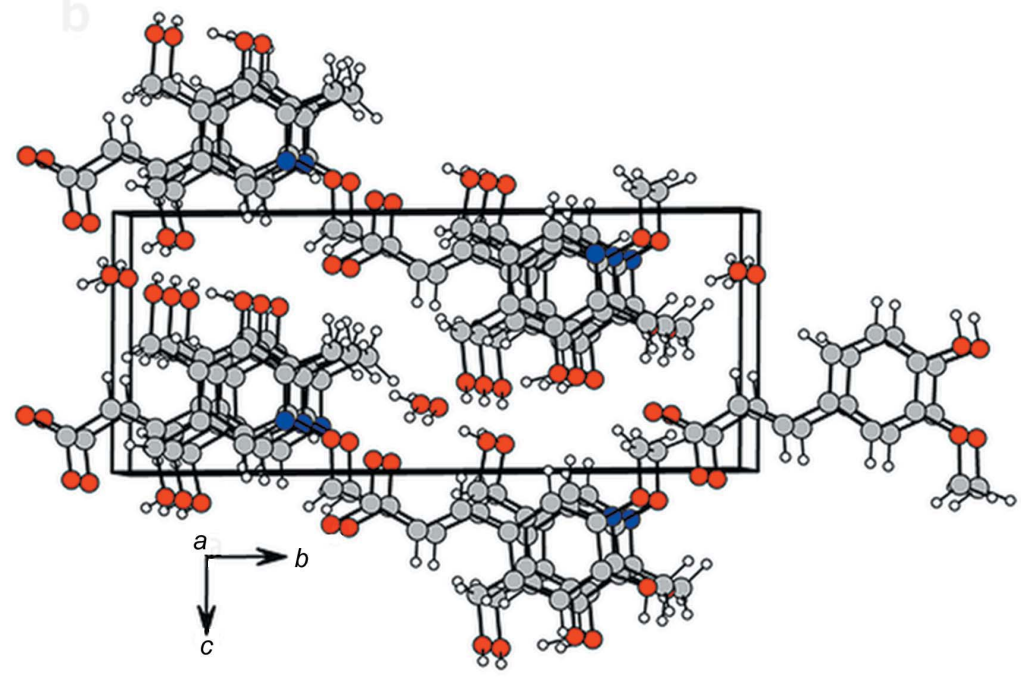

(b)

Figure 5

(a) The unit-cell contents of (2), viewed along the $b$ axis. Hydrogen bonds are drawn as dashed lines. (b) The crystal projection showing the molecular stacking.

formed. In salt (1), neighbouring aromatic rings of $\mathrm{PN}$ and syringic acid molecules are stacked at centroid-centroid $(C g \cdots C g)$ distances of 3.552 and $3.577 \AA$ in an almost parallel way, the mean dihedral angle between two adjacent molecules being $2.6^{\circ}$. Along the columns, the centroids of the aromatic rings are only slightly shifted, as shown by the angles formed by the $C g \rightarrow C g$ vector and the normal to the plane of one ring $\left(13.5\right.$ and $\left.16.2^{\circ}\right)$. In (2), the $C g \cdots C g$ distances become larger, due to the fact that the molecular layers are more puckered than in (1). Indeed, while the dihedral angle between two adjacent molecules is very similar $\left(1.3^{\circ}\right)$, the angles formed by the $\mathrm{Cg} \rightarrow \mathrm{Cg}$ vector and the normal to plane of one ring are larger, being 15.9 and $21.9^{\circ}$. Calculations concerning $\pi-\pi$ interactions were performed using PLATON (Spek, 2009).

A comparison can be made with an analogous series of PN cocrystals/salts published recently (Ganduri et al., 2015), where the coformers are 4-amino-, 4-hydroxy-, 4-cyano- and 4-nitrobenzoic acids. To better visualize and analyze all
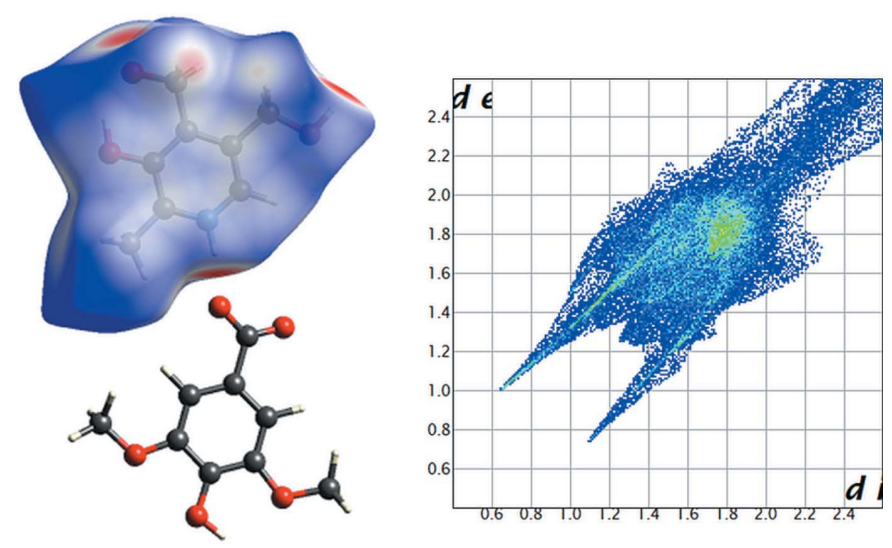

Figure 6

Hirshfeld surface and fingerprint plot for the PN molecule in (1). intermolecular interactions, Hirshfeld surfaces (HS) and their corresponding 2D fingergerprint plots (Hirshfeld, 1977; Spackman \& McKinnon, 2002; McKinnon et al., 2007) have been generated. The surfaces and plots of the PN molecule in (1) and (2) are shown in Figs. 6 and 7, respectively. The function mapped onto the Hirshfeld surface is $d_{\text {norm }}$, i.e. the normalized contact distance, defined in terms of $d_{\mathrm{e}}$ (distance to the nearest atoms outside), $d_{\mathrm{i}}$ (distance to the nearest atoms inside) and the van der Waals (vdW) radii of the two atoms external and internal to the surface; the red regions represent distances shorter than the sum of the vdW radii, while the white-coloured regions correspond to weak contacts and the blue-coloured regions are considered to be free of significant contacts. When the values of $d_{\mathrm{i}}$ and $d_{\mathrm{e}}$ for any HS surface point are plotted against each other, a fingerprint plot is obtained. Here, the different colours are related to the density of points giving that particular $d_{\mathrm{i}}-d_{\mathrm{e}}$ combination; for high density, the
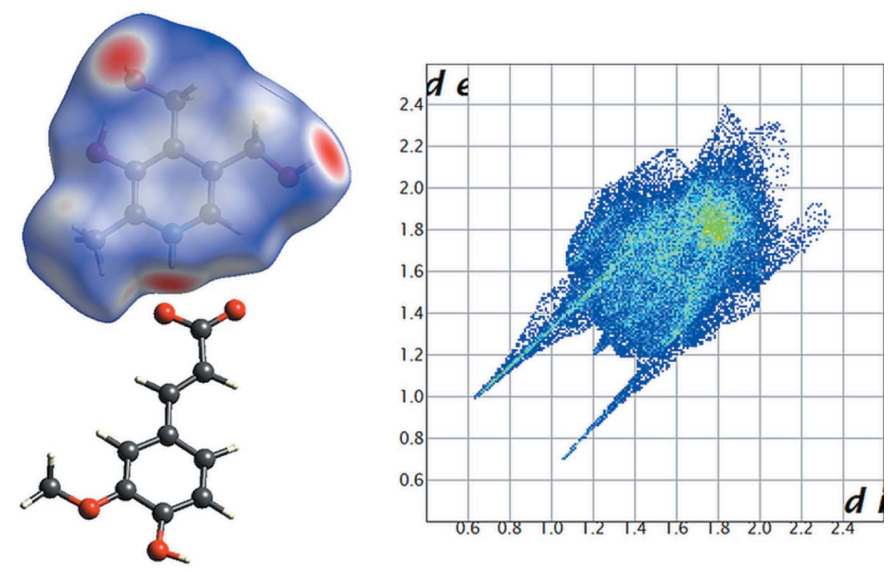

Figure 7

Hirshfeld surface and fingerprint plot for the PN molecule in (2). 


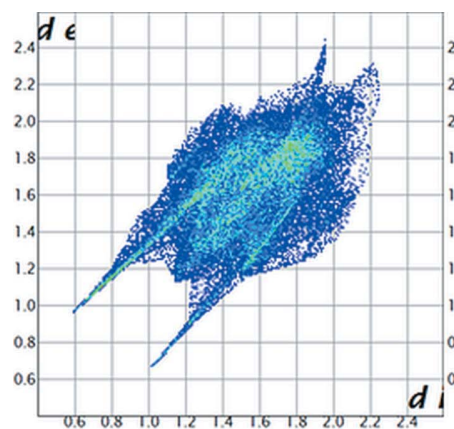

(a)

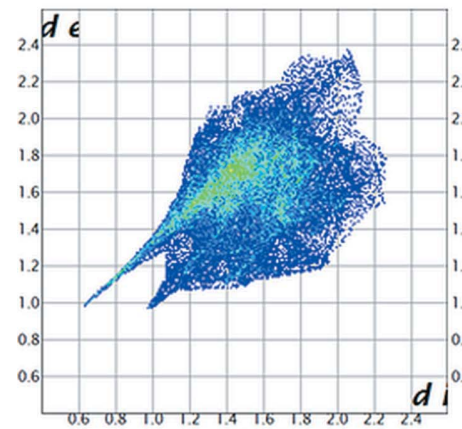

(c)

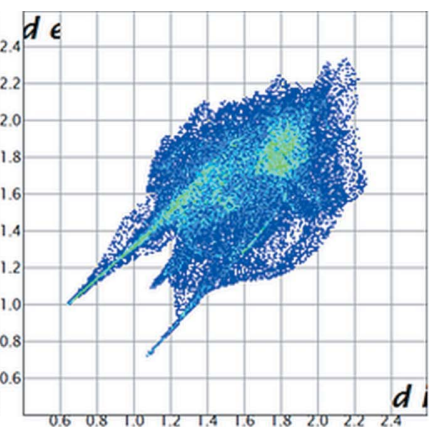

(b)

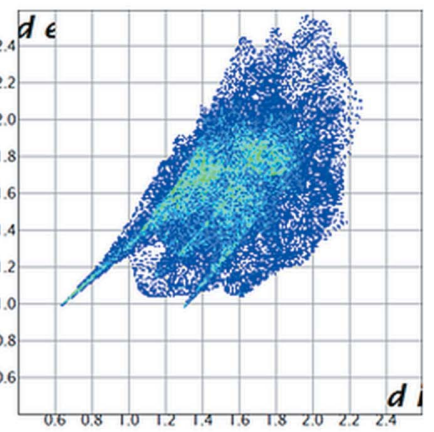

(d)
Figure 8

Fingerprint plots for the PN molecule in (a) 4-aminobenzoate, $(b)$ 4-hydroxybenzoate, $(c)$ 4-nitrobenzoate and $(d)$ 4-cyanobenzoate salts (Ganduri et al., 2015).

colour is red, for moderate density the colour is green and for relatively few points the colour is blue. It is also possible to highlight on the plot a single contact of the type atomtype $1 \cdots$ atomtype 2 , to focus attention on the individual interaction types present (Spackman \& Jayatilaka, 2009).

The surface coloured according to $d_{\text {norm }}(-0.72$ to $1.25 \AA)$ values shows where the short intermolecular interactions occur; in particular, the red spot corresponding to the interaction with the carboxylate group is represented in the fingerprints plot by the end of the sharper upper spike in both structures (Figs. 6 and 7); in this zone, the contribution of the $\mathrm{O}-\mathrm{H} \cdots \mathrm{O}$ hydrogen bond involving the $\mathrm{O} 1-\mathrm{H}$ PN hydroxy group is also added. The lower spike corresponds instead to $\mathrm{O} 7-\mathrm{H} 7 \mathrm{O} \cdots \mathrm{O} 2^{\text {iv }}$ and $\mathrm{O} 2-\mathrm{H} 2 \mathrm{O} \cdots \mathrm{O} 1^{\text {vii }}$ in (1) and (2), respectively, i.e. hydrogen bonds where $\mathrm{PN}$ is acting as the acceptor molecule. The central marker present in both fingerprint plots, formed by $\mathrm{C} \cdots \mathrm{C}$ and $\mathrm{C} \cdots \mathrm{N}$ interactions, is a typical and characteristic hint towards significant $\pi-\pi$ interactions (Spackman \& Jayatilaka, 2009). Examination of decomposed 2D fingerprint plots shows that the percentage of intermolecular $\mathrm{H} \cdots \mathrm{O}$ interactions is very similar in the two salts, viz. 36.1 and $29.8 \%$, respectively. The fingerprint plots of the PN molecule present in the literature salts mentioned above are shown in Fig. 8. The fingerprint plots of both the aminobenzoate and hydroxybenzoate salts (Figs. $8 a$ and $8 b$ ) show some similarities with the present structures, in particular, as far as the two sharp spikes are concerned. Indeed, they refer to similar $\mathrm{O} / \mathrm{N}-\mathrm{H} \cdots \mathrm{O}$ interactions, with $\mathrm{N} \cdots \mathrm{O}$ and $\mathrm{O} \cdots \mathrm{O}$ distances in the ranges $2.66-2.76$ and $2.65-2.90 \AA$, respectively. In nitro- and cyanobenzoate salts, the lower spike is much less evident (Figs. $8 c$ and $8 d$ ). Due to the lack of good hydrogen-bonding donor groups in the coformer molecule, in fact, they mark the existence of weaker $\mathrm{C}-\mathrm{H} \cdots \mathrm{O}$ interactions. The differences visible in the fingerprint plots shown in Fig. 8 may result also from different stacking types, i.e. heterogeneous in parts $(a)$ and $(b)$ and homogeneous in part (c). Moreover, in the case of cyanobenzoate (Fig. $8 d$ ), the aromatic rings are stacked at a distance greater than $4 \AA$ and accordingly no marker appears in the fingerprint plot. These findings, besides indicating the robustness of the pyridine/ carboxylic acid supramolecular synthon, point to its importance in driving the assembly process of different cocrystal units.

\section{References}

Almarsson, Ö., Hickey, M. B., Peterson, M. L., Morissette, S. L., Soukasene, S., McNulty, C., Tawa, M., MacPhee, J. M. \& Remenar, J. F. (2003). Cryst. Growth Des. 3, 927-933.

Altomare, A., Burla, M. C., Camalli, M., Cascarano, G. L., Giacovazzo, C., Guagliardi, A., Moliterni, A. G. G., Polidori, G. \& Spagna, R. (1999). J. Appl. Cryst. 32, 115-119.

André, I., Foces-Foces, C., Cano, F. H. \& Martinez-Ripoll, M. (1997). Acta Cryst. B53, 984-995.

Bak, A., Gore, A., Yanez, E., Stanton, M., Tufekcic, S., Syed, R., Akrami, A., Rose, M., Surapaneni, S., Bostick, T., King, A., Neervannan, S., Ostovic, D. \& Koparkar, A. (2008). J. Pharm. Sci. 97, 3942-3956.

Battini, S., Maddileti, D. \& Nangia, A. (2014). Cryst. Growth Des. 14, 5991-6005.

Bhogala, B. R., Basavoju, S. \& Nangia, A. (2005). CrystEngComm, 7, 551-562.

Burnett, M. N. \& Johnson, C. K. (1996). ORTEPIII. Report ORNL6895. Oak Ridge National Laboratory, Tennessee, USA.

ChemAxon (2010). MarvinSketch. ChemAxon, Budapest, Hungary.

Cheney, M. L., Shan, N., Healey, E. R., Hanna, M., Wojtas, E., Zaworotko, M. J., Sava, V., Song, S. \& Sanchez-Ramos, J. R. (2010). Cryst. Growth Des. 10, 394-405.

Childs, S. L., Stahly, G. P. \& Park, A. (2007). Mol. Pharm. 4, 323-338.

Chuysinuan, P., Chimnoi, N., Techasakul, S. \& Supaphol, P. (2009). Macromol. Chem. Phys. 210, 814-822.

Cvetkovski, A., Bertolasi, V. \& Ferretti, V. (2016). Acta Cryst. B72, 326-334.

Cvetkovski, A. \& Ferretti, V. (2016). Crystallogr. Rep. 61, 611-615.

Dalpiaz, A., Pavan, B. \& Ferretti, V. (2017). Drug Discov. Today, 22, 1134-1138.

EMA (2014). Reflection paper on the use of cocrystals and other solid state forms of active substances in medicinal products. Dated Feb 15, 2014. http://www.ema.europa.eu/docs/en_GB/document_library/Scientific_guideline/2015/07/WC500189927.pdf.

Erdemgil, F. Z., Şanli, S., Şanli, N., Özkan, G., Barbosa, J., Guiteras, J. \& Beltrán, J. L. (2007). Talanta, 72, 489-496.

Farrugia, L. J. (2012). J. Appl. Cryst. 45, 849-854.

FDA (2016). Draft Guidance. Regulatory Classification of Pharmaceutical Co-crystals. Dated August 2016. https://www.fda.gov/ downloads/Drugs/Guidances/UCM516813.pdf.

Ferretti, V., Dalpiaz, A., Bertolasi, V., Ferraro, L., Beggiato, S., Spizzo, F., Spisni, E. \& Pavan, B. (2015). Mol. Pharm. 12, 1501-1511.

Ganduri, R., Cherukuvada, S. \& Row, T. N. G. (2015). Cryst. Growth Des. 15, 3474-3480.

Good, D. J. \& Rodríguez-Hornedo, N. (2009). Cryst. Growth Des. 9, 2252-2264.

Goud, N. R., Gangavaram, S., Suresh, K., Pal, S., Manjunatha, S. G., Nambiar, S. \& Nangia, A. (2012). J. Pharm. Sci. 101, 664-680.

Hirshfeld, F. L. (1977). Theor. Chim. Acta, 44, 129-138. 
Jung, M. S., Kim, J. S., Kim, M. S., Alhalaweh, A., Cho, W., Hwang, S. J. \& Velaga, S. P. (2010). J. Pharm. Pharmacol. 62, 1560-1568.

McKinnon, J. J., Jayatilaka, D. \& Spackman, M. A. (2007). Chem. Commun. pp. 3814-3816.

Mooney, S., Leuendorf, J. E., Hendrickson, C. \& Hellmann, H. (2009). Molecules, 14, 329-351.

Morissette, S. L., Almarsson, O., Peterson, M. L., Remenar, J. F., Read, M. J., Lemmo, A. V., Ellis, S., Cima, M. J. \& Gardner, C. R. (2004). Adv. Drug Deliv. Rev. 56, 275-300.

Nehm, S. J., Rodríguez-Spong, B. \& Rodríguez-Hornedo, N. (2006). Cryst. Growth Des. 6, 592-600.

Newman, A. \& Wenslow, R. (2016). AAPS Open, 2:2, 1-11.

Nonius (1997). COLLECT. Nonius BV, Delft, The Netherlands.

Otwinowski, Z. \& Minor, W. (1997). Methods in Enzymology, Vol. 276, Macromolecular Crystallography, Part A, edited by C. W. Carter Jr \& R. M. Sweet, pp. 307-326. New York: Academic Press.

Parsons, S., Flack, H. D. \& Wagner, T. (2013). Acta Cryst. B69, 249259.
Santos, T. D. A. D. D., Costa, D. O. D., Pita, S. S. D. R. \& Semaan, F. S. (2010). Eclet. Quim. 35, 81-86.

Shan, N., Perr, M. L., Weyna, D. R. \& Zaworotko, M. J. (2014). Expert Opin. Drug Metab. Toxicol. 10, 1255-1271.

Sheldrick, G. M. (2015). Acta Cryst. C71, 3-8.

Spackman, M. \& Jayatilaka, D. (2009). CrystEngComm, 11, 19-32.

Spackman, M. A. \& McKinnon, J. J. (2002). CrystEngComm, 4, 378392.

Spek, A. L. (2009). Acta Cryst. D65, 148-155.

Spek, A. L. (2015). Acta Cryst. C71, 9-18.

Suresh, K., Chaitanya Mannava, M. K. \& Nangia, A. (2014). RSC Adv. 4, 58357-58361.

Suresh, K., Mannava, M. K. \& Nangia, A. (2016). Chem. Commun. 52 , 4223-4226.

Trask, A. V. (2007). Mol. Pharm. 4, 301-309.

Urbanski, T. (1949). Research, 2, 507-512.

Wolff, S. K., Grimwood, D. J., McKinnon, J. J., Turner, M. J., Jayatilaka, D. \& Spackman, M. A. (2012). CrystalExplorer. Version 3.0. University of Western Australia. 


\section{supporting information}

Acta Cryst. (2017). C73, 1064-1070 [https://doi.org/10.1107/S2053229617015765]

\section{New pharmaceutical salts containing pyridoxine}

\section{Aleksandar Cvetkovski, Valeria Ferretti and Valerio Bertolasi}

Computing details

For both structures, data collection: COLLECT (Nonius, 1997); cell refinement: DENZO-SMN (Otwinowski \& Minor, 1997); data reduction: DENZO-SMN (Otwinowski \& Minor, 1997); program(s) used to solve structure: SIR97 (Altomare et al., 1999); program(s) used to refine structure: SHELXL2014 (Sheldrick, 2015); molecular graphics: ORTEPIII (Burnett \& Johnson, 1996) and MarvinSketch (ChemAxon, 2010); software used to prepare material for publication: SHELXL2014 (Sheldrick, 2015) and WinGX (Farrugia, 2012).

3-Hydroxy-4,5-bis(hydroxymethyl)-2-methylpyridin-1-ium 4-hydroxy-3,5-dimethoxybenzoate monohydrate (shelx1)

Crystal data

$\mathrm{C}_{8} \mathrm{H}_{12} \mathrm{NO}_{3} \cdot \mathrm{C}_{9} \mathrm{H}_{9} \mathrm{O}_{5}$

$M_{r}=367.35$

Triclinic, $P \overline{1}$

$a=6.9085(2) \AA$

$b=8.4524(2) \AA$

$c=17.9702(5) \AA$

$\alpha=101.8010(16)^{\circ}$

$\beta=92.7110(16)^{\circ}$

$\gamma=109.8290(14)^{\circ}$

$V=958.47(5) \AA^{3}$

Data collection

Nonius KappaCCD diffractometer $\varphi$ scans and $\omega$ scans 18203 measured reflections 4387 independent reflections 3191 reflections with $I>2 \sigma(I)$

\section{Refinement}

Refinement on $F^{2}$ Least-squares matrix: full $R\left[F^{2}>2 \sigma\left(F^{2}\right)\right]=0.053$

$w R\left(F^{2}\right)=0.167$

$S=1.06$

4387 reflections

256 parameters

0 restraints

Hydrogen site location: mixed
$Z=2$

$F(000)=388$

$D_{\mathrm{x}}=1.273 \mathrm{Mg} \mathrm{m}^{-3}$

Mo $K \alpha$ radiation, $\lambda=0.71073 \AA$

Cell parameters from 18203 reflections

$\theta=3-27^{\circ}$

$\mu=0.10 \mathrm{~mm}^{-1}$

$T=295 \mathrm{~K}$

Plate, colourless

$0.52 \times 0.20 \times 0.09 \mathrm{~mm}$

$R_{\text {int }}=0.035$

$\theta_{\max }=27.5^{\circ}, \theta_{\min }=3.1^{\circ}$

$h=-8 \rightarrow 8$

$k=-10 \rightarrow 10$

$l=-23 \rightarrow 23$

$\mathrm{H}$ atoms treated by a mixture of independent and constrained refinement

$w=1 /\left[\sigma^{2}\left(F_{\mathrm{o}}^{2}\right)+(0.0972 P)^{2}+0.1657 P\right]$

where $P=\left(F_{\mathrm{o}}^{2}+2 F_{\mathrm{c}}^{2}\right) / 3$

$(\Delta / \sigma)_{\max }<0.001$

$\Delta \rho_{\max }=0.38$ e $\AA^{-3}$

$\Delta \rho_{\min }=-0.27$ e $\AA^{-3}$ 
Extinction correction: SHELXL2014

(Sheldrick, 2015),

$\mathrm{Fc}^{*}=\mathrm{kFc}\left[1+0.001 \mathrm{xFc}^{2} \lambda^{3} / \sin (2 \theta)\right]^{-1 / 4}$

Extinction coefficient: 0.049 (12)

Special details

Geometry. All esds (except the esd in the dihedral angle between two 1.s. planes) are estimated using the full covariance matrix. The cell esds are taken into account individually in the estimation of esds in distances, angles and torsion angles; correlations between esds in cell parameters are only used when they are defined by crystal symmetry. An approximate (isotropic) treatment of cell esds is used for estimating esds involving 1.s. planes.

Fractional atomic coordinates and isotropic or equivalent isotropic displacement parameters $\left(\AA^{2}\right)$

\begin{tabular}{|c|c|c|c|c|}
\hline & $x$ & $y$ & $z$ & $U_{\text {iso }} * / U_{\text {eq }}$ \\
\hline N1 & $0.0285(2)$ & $0.59703(18)$ & $0.20164(8)$ & $0.0356(3)$ \\
\hline $\mathrm{O} 1$ & $0.1171(3)$ & $0.72836(18)$ & $-0.00103(9)$ & $0.0750(6)$ \\
\hline $\mathrm{O} 2$ & $0.2464(2)$ & $1.24197(14)$ & $0.27041(7)$ & $0.0437(3)$ \\
\hline $\mathrm{O} 3$ & $0.2151(2)$ & $0.99184(17)$ & $0.34344(7)$ & $0.0500(4)$ \\
\hline $\mathrm{O} 4$ & $-0.0942(2)$ & $0.26847(15)$ & $0.21330(8)$ & $0.0491(4)$ \\
\hline O5 & $-0.2842(3)$ & $0.0993(2)$ & $0.10465(8)$ & $0.0679(5)$ \\
\hline O6 & $-0.3275(2)$ & $-0.10970(16)$ & $0.40501(7)$ & $0.0571(4)$ \\
\hline $\mathrm{O} 7$ & $-0.4868(2)$ & $-0.42453(16)$ & $0.32123(7)$ & $0.0503(4)$ \\
\hline O8 & $-0.5267(2)$ & $-0.49958(15)$ & $0.16857(7)$ & $0.0530(4)$ \\
\hline $\mathrm{C} 1$ & $0.0551(2)$ & $0.6461(2)$ & $0.13492(10)$ & $0.0355(4)$ \\
\hline H1 & 0.0187 & 0.5630 & 0.0888 & $0.043 *$ \\
\hline $\mathrm{C} 2$ & $0.1360(3)$ & $0.8185(2)$ & $0.13488(9)$ & $0.0352(4)$ \\
\hline $\mathrm{C} 3$ & $0.1906(2)$ & $0.9421(2)$ & $0.20504(10)$ & $0.0351(4)$ \\
\hline $\mathrm{C} 4$ & $0.1620(3)$ & $0.8850(2)$ & $0.27271(10)$ & $0.0358(4)$ \\
\hline $\mathrm{C} 5$ & $0.0775(3)$ & $0.7085(2)$ & $0.27035(9)$ & $0.0358(4)$ \\
\hline C6 & $0.1681(3)$ & $0.8730(2)$ & $0.06041(10)$ & $0.0484(5)$ \\
\hline H6A & 0.0821 & 0.9399 & 0.0530 & $0.058^{*}$ \\
\hline H6B & 0.3118 & 0.9460 & 0.0622 & $0.058^{*}$ \\
\hline $\mathrm{C} 7$ & $0.2845(3)$ & $1.1324(2)$ & $0.20618(12)$ & $0.0475(5)$ \\
\hline $\mathrm{H} 7 \mathrm{~A}$ & 0.4332 & 1.1639 & 0.2061 & $0.057 *$ \\
\hline H7B & 0.2289 & 1.1520 & 0.1597 & $0.057 *$ \\
\hline $\mathrm{C} 8$ & 0.0449 (3) & $0.6418(3)$ & $0.34144(11)$ & $0.0504(5)$ \\
\hline H8A & -0.0269 & 0.5188 & 0.3277 & $0.076 *$ \\
\hline H8B & -0.0361 & 0.6959 & 0.3719 & $0.076^{*}$ \\
\hline $\mathrm{H} 8 \mathrm{C}$ & 0.1769 & 0.6680 & 0.3704 & $0.076 *$ \\
\hline C9 & -0.2191 & $0.1241(2)$ & $0.17279(11)$ & $0.0406(4)$ \\
\hline $\mathrm{C} 10$ & $-0.2906(2)$ & -0.0230 & $0.21191(9)$ & $0.0344(4)$ \\
\hline $\mathrm{C} 11$ & -0.3779 & $-0.1917(2)$ & $0.16787(9)$ & 0.0359 (4) \\
\hline H11 & -0.3938 & -0.2134 & 0.1147 & $0.043^{*}$ \\
\hline $\mathrm{C} 12$ & -0.4411 & $-0.3270(2)$ & $0.20417(9)$ & $0.0352(4)$ \\
\hline $\mathrm{C} 13$ & $-0.4236(3)$ & $-0.2945(2)$ & $0.28378(9)$ & $0.0361(4)$ \\
\hline $\mathrm{C} 14$ & $-0.3377(3)$ & $-0.1254(2)$ & $0.32759(9)$ & $0.0374(4)$ \\
\hline $\mathrm{C} 15$ & -0.2698 & $0.0107(2)$ & $0.29161(10)$ & $0.0368(4)$ \\
\hline H15 & -0.2106 & 0.1239 & 0.3206 & $0.044^{*}$ \\
\hline $\mathrm{C} 16$ & $-0.5400(4)$ & -0.5445 & $0.08700(11)$ & $0.0617(6)$ \\
\hline
\end{tabular}




\begin{tabular}{lllll} 
H16A & -0.4507 & -0.4482 & 0.0697 & $0.093^{*}$ \\
H16B & -0.6805 & -0.5734 & 0.0650 & $0.093^{*}$ \\
H16C & -0.4978 & -0.6422 & 0.0715 & $0.093^{*}$ \\
C17 & $-0.2404(5)$ & $0.0579(3)$ & $0.45295(13)$ & $0.0834(9)$ \\
H17A & -0.1217 & 0.1245 & 0.4326 & $0.125^{*}$ \\
H17B & -0.1986 & 0.0504 & 0.5034 & $0.125^{*}$ \\
H17C & -0.3415 & 0.1130 & 0.4554 & $0.125^{*}$ \\
H1O & $0.155(4)$ & $0.770(4)$ & $-0.0395(17)$ & $0.080(8)^{*}$ \\
H2O & $0.123(5)$ & $1.243(4)$ & $0.2578(18)$ & $0.097(10)^{*}$ \\
H3O & $0.252(5)$ & $1.108(4)$ & $0.3378(18)$ & $0.102(10)^{*}$ \\
H1N & $-0.019(3)$ & $0.482(3)$ & $0.2007(11)$ & $0.046(5)^{*}$ \\
H7O & $-0.554(4)$ & $-0.525(4)$ & $0.2870(16)$ & $0.074(8)^{*}$ \\
\hline
\end{tabular}

Atomic displacement parameters $\left(\AA^{2}\right)$

\begin{tabular}{lllllll}
\hline & $U^{11}$ & $U^{22}$ & $U^{33}$ & $U^{12}$ & $U^{13}$ & $U^{23}$ \\
\hline $\mathrm{N} 1$ & $0.0409(7)$ & $0.0255(7)$ & $0.0409(8)$ & $0.0094(6)$ & $0.0070(6)$ & $0.0128(6)$ \\
O1 & $0.1270(15)$ & $0.0346(7)$ & $0.0400(8)$ & $-0.0016(8)$ & $0.0173(9)$ & $0.0095(6)$ \\
O2 & $0.0503(8)$ & $0.0241(6)$ & $0.0490(7)$ & $0.0076(5)$ & $0.0025(6)$ & $0.0024(5)$ \\
O3 & $0.0740(9)$ & $0.0329(7)$ & $0.0379(7)$ & $0.0146(6)$ & $0.0051(6)$ & $0.0049(5)$ \\
O4 & $0.0563(8)$ & $0.0271(6)$ & $0.0626(8)$ & $0.0084(5)$ & $0.0065(6)$ & $0.0191(6)$ \\
O5 & $0.0870(11)$ & $0.0577(9)$ & $0.0480(8)$ & $0.0022(8)$ & $0.0044(7)$ & $0.0303(7)$ \\
O6 & $0.0896(11)$ & $0.0348(7)$ & $0.0301(6)$ & $0.0022(7)$ & $0.0041(6)$ & $0.0066(5)$ \\
O7 & $0.0725(9)$ & $0.0283(6)$ & $0.0394(7)$ & $0.0005(6)$ & $0.0056(6)$ & $0.0150(5)$ \\
O8 & $0.0810(10)$ & $0.0268(6)$ & $0.0364(7)$ & $0.0030(6)$ & $0.0077(6)$ & $0.0035(5)$ \\
C1 & $0.0388(8)$ & $0.0284(8)$ & $0.0376(8)$ & $0.0086(6)$ & $0.0059(7)$ & $0.0095(6)$ \\
C2 & $0.0376(8)$ & $0.0292(8)$ & $0.0393(9)$ & $0.0105(6)$ & $0.0070(7)$ & $0.0113(7)$ \\
C3 & $0.0383(8)$ & $0.0251(7)$ & $0.0432(9)$ & $0.0111(6)$ & $0.0095(7)$ & $0.0104(6)$ \\
C4 & $0.0428(8)$ & $0.0277(8)$ & $0.0369(8)$ & $0.0132(7)$ & $0.0048(7)$ & $0.0070(6)$ \\
C5 & $0.0427(9)$ & $0.0293(8)$ & $0.0374(8)$ & $0.0133(7)$ & $0.0056(7)$ & $0.0116(6)$ \\
C6 & $0.0672(12)$ & $0.0320(9)$ & $0.0423(10)$ & $0.0094(8)$ & $0.0113(9)$ & $0.0136(7)$ \\
C7 & $0.0585(11)$ & $0.0251(8)$ & $0.0588(11)$ & $0.0121(8)$ & $0.0202(9)$ & $0.0117(8)$ \\
C8 & $0.0719(13)$ & $0.0418(10)$ & $0.0416(10)$ & $0.0195(9)$ & $0.0106(9)$ & $0.0194(8)$ \\
C9 & $0.0429(9)$ & $0.0353(9)$ & $0.0478(10)$ & $0.0123(7)$ & $0.0134(7)$ & $0.0199(7)$ \\
C10 & $0.0348(8)$ & $0.0288(8)$ & $0.0399(9)$ & $0.0082(6)$ & $0.0070(6)$ & $0.0134(6)$ \\
C11 & $0.0401(8)$ & $0.0332(8)$ & $0.0328(8)$ & $0.0086(7)$ & $0.0073(6)$ & $0.0112(6)$ \\
C12 & $0.0390(8)$ & $0.0272(8)$ & $0.0339(8)$ & $0.0050(6)$ & $0.0041(6)$ & $0.0070(6)$ \\
C13 & $0.0416(8)$ & $0.0266(8)$ & $0.0365(8)$ & $0.0052(6)$ & $0.0057(7)$ & $0.0115(7)$ \\
C14 & $0.0451(9)$ & $0.0303(8)$ & $0.0312(8)$ & $0.0058(7)$ & $0.0048(7)$ & $0.0083(6)$ \\
C15 & $0.0411(8)$ & $0.0242(7)$ & $0.0400(9)$ & $0.0049(6)$ & $0.0055(7)$ & $0.0082(6)$ \\
C16 & $0.0843(15)$ & $0.0441(11)$ & $0.0381(10)$ & $0.0057(10)$ & $0.0084(10)$ & $-0.0012(8)$ \\
C17 & $0.136(2)$ & $0.0461(12)$ & $0.0380(11)$ & $0.0031(14)$ & $0.0042(13)$ & $-0.0030(9)$ \\
& & & & & & \\
& & & & & &
\end{tabular}

Geometric parameters ( $\left.\AA,{ }^{\circ}\right)$

\begin{tabular}{llll}
\hline $\mathrm{N} 1-\mathrm{C} 5$ & $1.340(2)$ & $\mathrm{C} 5-\mathrm{C} 8$ & $1.495(2)$ \\
$\mathrm{N} 1-\mathrm{C} 1$ & $1.347(2)$ & $\mathrm{C} 6-\mathrm{H} 6 \mathrm{~A}$ & 0.9700 \\
$\mathrm{~N} 1-\mathrm{H} 1 \mathrm{~N}$ & $0.91(2)$ & $\mathrm{C} 6-\mathrm{H} 6 \mathrm{~B}$ & 0.9700
\end{tabular}




\begin{tabular}{|c|c|c|c|}
\hline $\mathrm{O} 1-\mathrm{C} 6$ & $1.399(2)$ & $\mathrm{C} 7-\mathrm{H} 7 \mathrm{~A}$ & 0.9700 \\
\hline $\mathrm{O} 1-\mathrm{H} 1 \mathrm{O}$ & $0.85(3)$ & $\mathrm{C} 7-\mathrm{H} 7 \mathrm{~B}$ & 0.9700 \\
\hline $\mathrm{O} 2-\mathrm{C} 7$ & $1.420(2)$ & $\mathrm{C} 8-\mathrm{H} 8 \mathrm{~A}$ & 0.9600 \\
\hline $\mathrm{O} 2-\mathrm{H} 2 \mathrm{O}$ & $0.87(3)$ & $\mathrm{C} 8-\mathrm{H} 8 \mathrm{~B}$ & 0.9600 \\
\hline $\mathrm{O} 3-\mathrm{C} 4$ & $1.352(2)$ & $\mathrm{C} 8-\mathrm{H} 8 \mathrm{C}$ & 0.9600 \\
\hline $\mathrm{O} 3-\mathrm{H} 3 \mathrm{O}$ & $0.95(3)$ & $\mathrm{C} 9-\mathrm{C} 10$ & $1.503(2)$ \\
\hline $\mathrm{O} 4-\mathrm{C} 9$ & $1.275(2)$ & $\mathrm{C} 10-\mathrm{C} 11$ & $1.390(2)$ \\
\hline $\mathrm{O} 5-\mathrm{C} 9$ & $1.235(2)$ & $\mathrm{C} 10-\mathrm{C} 15$ & $1.393(2)$ \\
\hline $\mathrm{O} 6-\mathrm{C} 14$ & $1.366(2)$ & $\mathrm{C} 11-\mathrm{C} 12$ & $1.385(2)$ \\
\hline $\mathrm{O} 6-\mathrm{C} 17$ & $1.409(2)$ & C11-H11 & 0.9300 \\
\hline $\mathrm{O} 7-\mathrm{C} 13$ & $1.3626(19)$ & $\mathrm{C} 12-\mathrm{C} 13$ & $1.392(2)$ \\
\hline $\mathrm{O} 7-\mathrm{H} 7 \mathrm{O}$ & $0.90(3)$ & $\mathrm{C} 13-\mathrm{C} 14$ & $1.391(2)$ \\
\hline $\mathrm{O} 8-\mathrm{C} 12$ & 1.3727 (19) & $\mathrm{C} 14-\mathrm{C} 15$ & $1.389(2)$ \\
\hline $\mathrm{O} 8-\mathrm{C} 16$ & $1.427(2)$ & $\mathrm{C} 15-\mathrm{H} 15$ & 0.9300 \\
\hline $\mathrm{C} 1-\mathrm{C} 2$ & $1.372(2)$ & $\mathrm{C} 16-\mathrm{H} 16 \mathrm{~A}$ & 0.9600 \\
\hline $\mathrm{C} 1-\mathrm{H} 1$ & 0.9300 & $\mathrm{C} 16-\mathrm{H} 16 \mathrm{~B}$ & 0.9600 \\
\hline $\mathrm{C} 2-\mathrm{C} 3$ & $1.405(2)$ & $\mathrm{C} 16-\mathrm{H} 16 \mathrm{C}$ & 0.9600 \\
\hline $\mathrm{C} 2-\mathrm{C} 6$ & $1.505(2)$ & C17-H17A & 0.9600 \\
\hline $\mathrm{C} 3-\mathrm{C} 4$ & $1.396(2)$ & $\mathrm{C} 17-\mathrm{H} 17 \mathrm{~B}$ & 0.9600 \\
\hline $\mathrm{C} 3-\mathrm{C} 7$ & $1.512(2)$ & $\mathrm{C} 17-\mathrm{H} 17 \mathrm{C}$ & 0.9600 \\
\hline $\mathrm{C} 4-\mathrm{C} 5$ & $1.396(2)$ & & \\
\hline $\mathrm{C} 5-\mathrm{N} 1-\mathrm{C} 1$ & $123.59(14)$ & $\mathrm{H} 8 \mathrm{~A}-\mathrm{C} 8-\mathrm{H} 8 \mathrm{~B}$ & 109.5 \\
\hline $\mathrm{C} 5-\mathrm{N} 1-\mathrm{H} 1 \mathrm{~N}$ & $117.5(13)$ & $\mathrm{C} 5-\mathrm{C} 8-\mathrm{H} 8 \mathrm{C}$ & 109.5 \\
\hline $\mathrm{C} 1-\mathrm{N} 1-\mathrm{H} 1 \mathrm{~N}$ & $118.8(13)$ & $\mathrm{H} 8 \mathrm{~A}-\mathrm{C} 8-\mathrm{H} 8 \mathrm{C}$ & 109.5 \\
\hline $\mathrm{C} 6-\mathrm{O} 1-\mathrm{H} 1 \mathrm{O}$ & $104.7(19)$ & $\mathrm{H} 8 \mathrm{~B}-\mathrm{C} 8-\mathrm{H} 8 \mathrm{C}$ & 109.5 \\
\hline $\mathrm{C} 7-\mathrm{O} 2-\mathrm{H} 2 \mathrm{O}$ & $105(2)$ & $\mathrm{O} 5-\mathrm{C} 9-\mathrm{O} 4$ & $124.23(16)$ \\
\hline $\mathrm{C} 4-\mathrm{O} 3-\mathrm{H} 3 \mathrm{O}$ & $108.1(19)$ & $\mathrm{O} 5-\mathrm{C} 9-\mathrm{C} 10$ & $118.93(16)$ \\
\hline $\mathrm{C} 14-\mathrm{O} 6-\mathrm{C} 17$ & $117.84(15)$ & $\mathrm{O} 4-\mathrm{C} 9-\mathrm{C} 10$ & $116.84(16)$ \\
\hline $\mathrm{C} 13-\mathrm{O} 7-\mathrm{H} 7 \mathrm{O}$ & $109.3(17)$ & $\mathrm{C} 11-\mathrm{C} 10-\mathrm{C} 15$ & $120.72(14)$ \\
\hline $\mathrm{C} 12-\mathrm{O} 8-\mathrm{C} 16$ & $117.14(14)$ & $\mathrm{C} 11-\mathrm{C} 10-\mathrm{C} 9$ & $119.43(15)$ \\
\hline $\mathrm{N} 1-\mathrm{C} 1-\mathrm{C} 2$ & $120.10(15)$ & $\mathrm{C} 15-\mathrm{C} 10-\mathrm{C} 9$ & $119.85(15)$ \\
\hline $\mathrm{N} 1-\mathrm{C} 1-\mathrm{H} 1$ & 120.0 & $\mathrm{C} 12-\mathrm{C} 11-\mathrm{C} 10$ & $119.23(15)$ \\
\hline $\mathrm{C} 2-\mathrm{C} 1-\mathrm{H} 1$ & 120.0 & $\mathrm{C} 12-\mathrm{C} 11-\mathrm{H} 11$ & 120.4 \\
\hline $\mathrm{C} 1-\mathrm{C} 2-\mathrm{C} 3$ & $119.16(15)$ & $\mathrm{C} 10-\mathrm{C} 11-\mathrm{H} 11$ & 120.4 \\
\hline $\mathrm{C} 1-\mathrm{C} 2-\mathrm{C} 6$ & $120.06(15)$ & $\mathrm{O} 8-\mathrm{C} 12-\mathrm{C} 11$ & $125.88(15)$ \\
\hline $\mathrm{C} 3-\mathrm{C} 2-\mathrm{C} 6$ & $120.77(14)$ & $\mathrm{O} 8-\mathrm{C} 12-\mathrm{C} 13$ & $113.64(14)$ \\
\hline $\mathrm{C} 4-\mathrm{C} 3-\mathrm{C} 2$ & $118.66(14)$ & $\mathrm{C} 11-\mathrm{C} 12-\mathrm{C} 13$ & $120.47(15)$ \\
\hline $\mathrm{C} 4-\mathrm{C} 3-\mathrm{C} 7$ & $121.44(15)$ & $\mathrm{O} 7-\mathrm{C} 13-\mathrm{C} 14$ & $118.00(15)$ \\
\hline $\mathrm{C} 2-\mathrm{C} 3-\mathrm{C} 7$ & $119.87(15)$ & $\mathrm{O} 7-\mathrm{C} 13-\mathrm{C} 12$ & $121.94(15)$ \\
\hline $\mathrm{O} 3-\mathrm{C} 4-\mathrm{C} 5$ & $115.73(15)$ & $\mathrm{C} 14-\mathrm{C} 13-\mathrm{C} 12$ & $120.06(14)$ \\
\hline $\mathrm{O} 3-\mathrm{C} 4-\mathrm{C} 3$ & $123.78(15)$ & $\mathrm{O} 6-\mathrm{C} 14-\mathrm{C} 15$ & $125.48(15)$ \\
\hline $\mathrm{C} 5-\mathrm{C} 4-\mathrm{C} 3$ & $120.48(15)$ & $\mathrm{O} 6-\mathrm{C} 14-\mathrm{C} 13$ & $114.76(14)$ \\
\hline $\mathrm{N} 1-\mathrm{C} 5-\mathrm{C} 4$ & $118.00(15)$ & $\mathrm{C} 15-\mathrm{C} 14-\mathrm{C} 13$ & $119.77(15)$ \\
\hline $\mathrm{N} 1-\mathrm{C} 5-\mathrm{C} 8$ & $119.78(14)$ & $\mathrm{C} 14-\mathrm{C} 15-\mathrm{C} 10$ & $119.72(15)$ \\
\hline $\mathrm{C} 4-\mathrm{C} 5-\mathrm{C} 8$ & $122.21(15)$ & $\mathrm{C} 14-\mathrm{C} 15-\mathrm{H} 15$ & 120.1 \\
\hline $\mathrm{O} 1-\mathrm{C} 6-\mathrm{C} 2$ & $110.61(14)$ & $\mathrm{C} 10-\mathrm{C} 15-\mathrm{H} 15$ & 120.1 \\
\hline $\mathrm{O} 1-\mathrm{C} 6-\mathrm{H} 6 \mathrm{~A}$ & 109.5 & $\mathrm{O} 8-\mathrm{C} 16-\mathrm{H} 16 \mathrm{~A}$ & 109.5 \\
\hline
\end{tabular}




$\begin{array}{llll}\mathrm{C} 2-\mathrm{C} 6-\mathrm{H} 6 \mathrm{~A} & 109.5 & \mathrm{O} 8-\mathrm{C} 16-\mathrm{H} 16 \mathrm{~B} & 109.5 \\ \mathrm{O} 1-\mathrm{C} 6-\mathrm{H} 6 \mathrm{~B} & 109.5 & \mathrm{H} 16 \mathrm{~A}-\mathrm{C} 16-\mathrm{H} 16 \mathrm{~B} & 109.5 \\ \mathrm{C} 2-\mathrm{C} 6-\mathrm{H} 6 \mathrm{~B} & 109.5 & \mathrm{O}-\mathrm{C} 16-\mathrm{H} 16 \mathrm{C} & 109.5 \\ \mathrm{H} 6 \mathrm{~A}-\mathrm{C} 6-\mathrm{H} 6 \mathrm{~B} & 108.1 & \mathrm{H} 16 \mathrm{~A}-\mathrm{C} 16-\mathrm{H} 16 \mathrm{C} & 109.5 \\ \text { O2-C7-C3 } & 113.71(14) & \mathrm{H} 16 \mathrm{~B}-\mathrm{C} 16-\mathrm{H} 16 \mathrm{C} & 109.5 \\ \text { O2-C7-H7A } & 108.8 & \mathrm{O}-\mathrm{C} 17-\mathrm{H} 17 \mathrm{~A} & 109.5 \\ \mathrm{C} 3-\mathrm{C} 7-\mathrm{H} 7 \mathrm{~A} & 108.8 & \mathrm{O}-\mathrm{C} 17-\mathrm{H} 17 \mathrm{~B} & 109.5 \\ \text { O2-C7-H7B } & 108.8 & \mathrm{H} 17 \mathrm{~A}-\mathrm{C} 17-\mathrm{H} 17 \mathrm{~B} & 109.5 \\ \mathrm{C} 3-\mathrm{C} 7-\mathrm{H} 7 \mathrm{~B} & 108.8 & \mathrm{O}-\mathrm{C} 17-\mathrm{H} 17 \mathrm{C} & 109.5 \\ \mathrm{H} 7 \mathrm{~A}-\mathrm{C} 7-\mathrm{H} 7 \mathrm{~B} & 107.7 & \mathrm{H} 17 \mathrm{~A}-\mathrm{C} 17-\mathrm{H} 17 \mathrm{C} & 109.5 \\ \mathrm{C} 5-\mathrm{C} 8-\mathrm{H} 8 \mathrm{~A} & 109.5 & \mathrm{H} 17 \mathrm{~B}-\mathrm{C} 17-\mathrm{H} 17 \mathrm{C} & 109.5 \\ \mathrm{C} 5-\mathrm{C} 8-\mathrm{H} 8 \mathrm{~B} & 109.5 & & \end{array}$

Hydrogen-bond geometry $\left(A,{ }^{\circ}\right)$

\begin{tabular}{lllll}
\hline$D-\mathrm{H} \cdots A$ & $D-\mathrm{H}$ & $\mathrm{H} \cdots A$ & $D \cdots A$ & $D-\mathrm{H} \cdots A$ \\
\hline $\mathrm{N} 1-\mathrm{H} 1 N \cdots \mathrm{O} 4$ & $0.91(2)$ & $1.77(2)$ & $2.671(2)$ & $171(2)$ \\
$\mathrm{O} 3-\mathrm{H} 3 O \cdots \mathrm{O} 2$ & $0.95(4)$ & $1.83(4)$ & $2.663(2)$ & $144(3)$ \\
$\mathrm{C} 8-\mathrm{H} 8 A \cdots \mathrm{O} 4$ & 0.96 & 2.52 & $3.308(2)$ & 139 \\
$\mathrm{C} 1-\mathrm{H} 1 \cdots \mathrm{O} 1^{\mathrm{i}}$ & 0.93 & 2.47 & $3.359(2)$ & 158 \\
$\mathrm{O} 1-\mathrm{H} 1 O \cdots \mathrm{O} 5^{\mathrm{i}}$ & $0.85(3)$ & $1.83(3)$ & $2.663(2)$ & $166(3)$ \\
$\mathrm{C} 6-\mathrm{H} 6 B \cdots \mathrm{O} 5^{\mathrm{ii}}$ & 0.97 & 2.64 & $3.576(3)$ & 161 \\
$\mathrm{O} 2-\mathrm{H} 2 O \cdots \mathrm{O} 4^{i i}$ & $0.87(4)$ & $1.77(4)$ & $2.620(2)$ & $165(3)$ \\
$\mathrm{O} 7-\mathrm{H} 7 O \cdots \mathrm{O} 2^{\mathrm{iv}}$ & $0.89(2)$ & $1.93(2)$ & $2.728(1)$ & $146(3)$
\end{tabular}

Symmetry codes: (i) $-x,-y+1,-z$; (ii) $x+1, y+1, z$; (iii) $x, y+1, z$; (iv) $x-1, y-2, z$.

3-Hydroxy-4,5-bis(hydroxymethyl)-2-methylpyridin-1-ium (E)-3-(4-hydroxy-3-methoxyphenyl)prop-2-enoate monohydrate (comp2)

Crystal data

$\mathrm{C}_{8} \mathrm{H}_{12} \mathrm{NO}_{3}{ }^{+} \cdot \mathrm{C}_{10} \mathrm{H}_{11} \mathrm{O}_{5}^{-} \cdot \mathrm{H}_{2} \mathrm{O}$

$M_{r}=381.37$

Monoclinic, $P 2_{1}$

$a=7.2440(3) \AA$

$b=17.1615(5) \AA$

$c=7.2706(2) \AA$

$\beta=98.806(2)^{\circ}$

$V=893.21(5) \AA^{3}$

$Z=2$

Data collection

Nonius Kappa CCD

diffractometer

$\varphi$ scans and $\omega$ scans

11173 measured reflections

4578 independent reflections

3822 reflections with $I>2 \sigma(I)$
$F(000)=404$

$D_{\mathrm{x}}=1.418 \mathrm{Mg} \mathrm{m}^{-3}$

Mo $K \alpha$ radiation, $\lambda=0.71073 \AA$

Cell parameters from 11173 reflections

$\theta=4-30^{\circ}$

$\mu=0.11 \mathrm{~mm}^{-1}$

$T=295 \mathrm{~K}$

Prismatic, colourless

$0.35 \times 0.22 \times 0.13 \mathrm{~mm}$

$$
\begin{aligned}
& R_{\text {int }}=0.034 \\
& \theta_{\text {max }}=30.0^{\circ}, \theta_{\text {min }}=4.5^{\circ} \\
& h=-10 \rightarrow 9 \\
& k=-24 \rightarrow 22 \\
& l=-10 \rightarrow 10
\end{aligned}
$$




\section{Refinement}

Refinement on $F^{2}$

Least-squares matrix: full

$R\left[F^{2}>2 \sigma\left(F^{2}\right)\right]=0.040$

$w R\left(F^{2}\right)=0.108$

$S=1.07$

4578 reflections

272 parameters

1 restraint

Hydrogen site location: mixed
$\mathrm{H}$ atoms treated by a mixture of independent and constrained refinement

$w=1 /\left[\sigma^{2}\left(F_{\mathrm{o}}^{2}\right)+(0.063 P)^{2}+0.0278 P\right]$

where $P=\left(F_{\mathrm{o}}^{2}+2 F_{\mathrm{c}}^{2}\right) / 3$

$(\Delta / \sigma)_{\max }<0.001$

$\Delta \rho_{\max }=0.27 \mathrm{e}^{-3}$

$\Delta \rho_{\min }=-0.18$ e $\AA^{-3}$

Absolute structure: Flack $x$ determined using 1452 quotients $[(\mathrm{I}+)-(\mathrm{I}-)] /[(\mathrm{I}+)+(\mathrm{I}-)]$ (Parsons et al., 2013)

Absolute structure parameter: -0.4 (4)

\section{Special details}

Geometry. All esds (except the esd in the dihedral angle between two 1.s. planes) are estimated using the full covariance matrix. The cell esds are taken into account individually in the estimation of esds in distances, angles and torsion angles; correlations between esds in cell parameters are only used when they are defined by crystal symmetry. An approximate (isotropic) treatment of cell esds is used for estimating esds involving l.s. planes.

Fractional atomic coordinates and isotropic or equivalent isotropic displacement parameters $\left(\AA^{2}\right)$

\begin{tabular}{|c|c|c|c|c|}
\hline & $x$ & $y$ & $z$ & $U_{\text {iso }} * / U_{\text {eq }}$ \\
\hline N1 & $0.8860(3)$ & $-0.19960(10)$ & $1.1832(2)$ & $0.0354(4)$ \\
\hline $\mathrm{O} 1$ & $0.7016(3)$ & $-0.39465(12)$ & $0.8941(2)$ & $0.0551(5)$ \\
\hline $\mathrm{O} 2$ & $0.9773(4)$ & $-0.40722(13)$ & $1.6750(3)$ & $0.0622(6)$ \\
\hline $\mathrm{O} 3$ & $1.0560(3)$ & $-0.26271(12)$ & $1.6424(2)$ & $0.0526(4)$ \\
\hline $\mathrm{O} 4$ & $0.7236(2)$ & $-0.12996(9)$ & $0.7844(2)$ & $0.0457(4)$ \\
\hline O5 & $0.8366(3)$ & $-0.05993(9)$ & $1.0310(2)$ & $0.0473(4)$ \\
\hline O6 & $0.4671(3)$ & $0.36773(9)$ & $0.5400(2)$ & $0.0492(4)$ \\
\hline $\mathrm{O} 7$ & $0.6240(3)$ & $0.35956(10)$ & $0.8823(2)$ & $0.0565(5)$ \\
\hline $\mathrm{O} 1 \mathrm{~W}$ & $0.5731(3)$ & $0.00760(11)$ & $1.2468(2)$ & $0.0502(4)$ \\
\hline $\mathrm{C} 1$ & $0.8257(3)$ & $-0.26552(12)$ & $1.0932(3)$ & $0.0352(4)$ \\
\hline $\mathrm{H} 1$ & 0.7760 & -0.2635 & 0.9675 & $0.042^{*}$ \\
\hline $\mathrm{C} 2$ & $0.8367(3)$ & $-0.33573(12)$ & $1.1852(3)$ & $0.0325(4)$ \\
\hline $\mathrm{C} 3$ & $0.9116(3)$ & $-0.33702(12)$ & $1.3759(3)$ & $0.0331(4)$ \\
\hline $\mathrm{C} 4$ & $0.9767(3)$ & $-0.26757(13)$ & $1.4613(3)$ & $0.0356(4)$ \\
\hline $\mathrm{C} 5$ & $0.9623(3)$ & $-0.19785(12)$ & $1.3625(3)$ & $0.0352(4)$ \\
\hline C6 & $0.7702(3)$ & $-0.40987(12)$ & $1.0846(3)$ & $0.0384(4)$ \\
\hline H6A & 0.8727 & -0.4467 & 1.0934 & $0.046^{*}$ \\
\hline H6B & 0.6719 & -0.4330 & 1.1434 & $0.046^{*}$ \\
\hline $\mathrm{C} 7$ & $0.9194(4)$ & $-0.41369(14)$ & $1.4799(3)$ & $0.0466(5)$ \\
\hline H7A & 0.7965 & -0.4374 & 1.4580 & $0.056^{*}$ \\
\hline H7B & 1.0047 & -0.4483 & 1.4291 & $0.056^{*}$ \\
\hline $\mathrm{C} 8$ & $1.0285(4)$ & $-0.12139(15)$ & $1.4478(3)$ & $0.0464(5)$ \\
\hline H8A & 1.0056 & -0.0810 & 1.3557 & $0.070^{*}$ \\
\hline H8B & 1.1599 & -0.1243 & 1.4931 & $0.070^{*}$ \\
\hline $\mathrm{H} 8 \mathrm{C}$ & 0.9622 & -0.1098 & 1.5492 & $0.070^{*}$ \\
\hline C9 & $0.7545(3)$ & $-0.06564(11)$ & $0.8646(3)$ & $0.0332(4)$ \\
\hline $\mathrm{C} 10$ & $0.6902(3)$ & $0.00681(12)$ & $0.7617(3)$ & $0.0368(4)$ \\
\hline $\mathrm{H} 10$ & 0.6318 & 0.0027 & 0.6390 & $0.044 *$ \\
\hline
\end{tabular}




$\begin{array}{lllll}\text { C11 } & 0.7130(3) & 0.07718(12) & 0.8386(3) & 0.0332(4) \\ \mathrm{H} 11 & 0.7754 & 0.0793 & 0.9602 & 0.040^{*} \\ \mathrm{C} 12 & 0.6508(3) & 0.15162(11) & 0.7528(3) & 0.0320(4) \\ \mathrm{C} 13 & 0.6705(3) & 0.21921(12) & 0.8628(3) & 0.0349(4) \\ \mathrm{H} 13 & 0.7248 & 0.2159 & 0.9871 & 0.042^{*} \\ \mathrm{C} 14 & 0.6101(3) & 0.29043(12) & 0.7888(3) & 0.0365(4) \\ \mathrm{C} 15 & 0.5249(3) & 0.29579(12) & 0.6022(3) & 0.0363(4) \\ \mathrm{C} 16 & 0.5067(3) & 0.22952(12) & 0.4926(3) & 0.0370(4) \\ \mathrm{H} 16 & 0.4518 & 0.2330 & 0.3686 & 0.044^{*} \\ \mathrm{C} 17 & 0.5697(3) & 0.15779(12) & 0.5661(3) & 0.0365(4) \\ \mathrm{H} 17 & 0.5578 & 0.1137 & 0.4907 & 0.044^{*} \\ \mathrm{C} 18 & 0.7096(4) & 0.35938(16) & 1.0716(3) & 0.0537(6) \\ \mathrm{H} 18 \mathrm{~A} & 0.6440 & 0.3241 & 1.1411 & 0.081^{*} \\ \mathrm{H} 18 \mathrm{~B} & 0.7053 & 0.4109 & 1.1221 & 0.081^{*} \\ \mathrm{H} 18 \mathrm{C} & 0.8373 & 0.3430 & 1.0797 & 0.081^{*} \\ \mathrm{H} 1 \mathrm{~N} & 0.879(5) & -0.153(3) & 1.116(5) & 0.080(11)^{*} \\ \mathrm{H} 1 \mathrm{O} & 0.614(4) & -0.428(2) & 0.855(4) & 0.046(7)^{*} \\ \mathrm{H} 2 \mathrm{O} & 0.877(8) & -0.403(3) & 1.737(7) & 0.115(18)^{*} \\ \mathrm{H} 3 \mathrm{O} & 1.038(6) & -0.313(3) & 1.674(6) & 0.081(12)^{*} \\ \mathrm{H} 6 \mathrm{O} & 0.396(5) & 0.360(3) & 0.422(6) & 0.080(11)^{*} \\ \mathrm{H} 1 \mathrm{~W} & 0.537(6) & -0.035(3) & 1.282(6) & 0.078(11)^{*} \\ \mathrm{H} 2 \mathrm{~W} & 0.674(7) & -0.007(3) & 1.196(6) & 0.100(14)^{*}\end{array}$

Atomic displacement parameters $\left(\AA^{2}\right)$

\begin{tabular}{|c|c|c|c|c|c|c|}
\hline & $U^{11}$ & $U^{22}$ & $U^{33}$ & $U^{12}$ & $U^{13}$ & $U^{23}$ \\
\hline N1 & $0.0409(9)$ & $0.0269(8)$ & $0.0361(8)$ & $0.0026(7)$ & $-0.0010(7)$ & $0.0031(7)$ \\
\hline O1 & $0.0745(13)$ & $0.0494(10)$ & $0.0396(9)$ & $-0.0207(10)$ & $0.0032(8)$ & $-0.0049(8)$ \\
\hline $\mathrm{O} 2$ & $0.0801(14)$ & $0.0624(13)$ & $0.0422(9)$ & $-0.0019(11)$ & $0.0025(9)$ & $0.0191(9)$ \\
\hline $\mathrm{O} 3$ & $0.0712(12)$ & $0.0515(10)$ & $0.0313(7)$ & $0.0014(9)$ & $-0.0048(7)$ & $-0.0008(7)$ \\
\hline $\mathrm{O} 4$ & $0.0667(10)$ & $0.0267(7)$ & $0.0392(8)$ & $0.0019(7)$ & $-0.0061(7)$ & $-0.0014(6)$ \\
\hline O5 & $0.0688(11)$ & $0.0296(7)$ & $0.0376(8)$ & $0.0047(7)$ & $-0.0103(7)$ & $0.0000(6)$ \\
\hline O6 & $0.0712(11)$ & $0.0276(8)$ & $0.0419(8)$ & $0.0069(8)$ & $-0.0129(7)$ & $0.0032(6)$ \\
\hline O7 & $0.0924(13)$ & $0.0285(8)$ & $0.0404(8)$ & $0.0096(9)$ & $-0.0163(8)$ & $-0.0027(7)$ \\
\hline $\mathrm{O} 1 \mathrm{~W}$ & $0.0700(12)$ & $0.0332(8)$ & $0.0473(9)$ & $0.0067(8)$ & $0.0082(8)$ & $0.0033(7)$ \\
\hline $\mathrm{C} 1$ & $0.0406(10)$ & $0.0300(9)$ & $0.0333(9)$ & $0.0005(9)$ & $-0.0001(8)$ & $0.0016(8)$ \\
\hline $\mathrm{C} 2$ & $0.0336(10)$ & $0.0292(9)$ & $0.0345(9)$ & $0.0019(8)$ & $0.0047(7)$ & $0.0000(8)$ \\
\hline C3 & $0.0360(10)$ & $0.0309(9)$ & $0.0330(9)$ & $0.0039(8)$ & $0.0079(7)$ & $0.0029(8)$ \\
\hline $\mathrm{C} 4$ & $0.0398(10)$ & $0.0366(10)$ & $0.0296(9)$ & $0.0051(9)$ & $0.0030(7)$ & $0.0021(8)$ \\
\hline C5 & $0.0368(10)$ & $0.0331(10)$ & $0.0348(9)$ & $0.0010(9)$ & $0.0021(8)$ & $-0.0023(8)$ \\
\hline C6 & $0.0443(11)$ & $0.0310(10)$ & $0.0399(10)$ & $-0.0038(9)$ & $0.0066(8)$ & $-0.0031(8)$ \\
\hline C7 & $0.0655(15)$ & $0.0356(11)$ & $0.0404(11)$ & $0.0078(11)$ & $0.0135(10)$ & $0.0098(9)$ \\
\hline $\mathrm{C} 8$ & $0.0552(13)$ & $0.0369(11)$ & $0.0440(11)$ & $-0.0023(10)$ & $-0.0017(9)$ & $-0.0060(9)$ \\
\hline C9 & $0.0392(10)$ & $0.0262(9)$ & $0.0333(9)$ & $0.0041(8)$ & $0.0025(7)$ & $0.0028(7)$ \\
\hline $\mathrm{C} 10$ & $0.0450(11)$ & $0.0296(9)$ & $0.0333(9)$ & $0.0015(9)$ & $-0.0017(8)$ & $0.0030(8)$ \\
\hline C11 & $0.0349(10)$ & 0.0289 (9) & 0.0347 (9) & $0.0010(8)$ & $0.0020(7)$ & $0.0036(8)$ \\
\hline $\mathrm{C} 12$ & $0.0331(10)$ & $0.0255(9)$ & $0.0365(9)$ & $0.0000(8)$ & $0.0022(7)$ & $0.0032(8)$ \\
\hline $\mathrm{C} 13$ & $0.0405(10)$ & $0.0296(10)$ & $0.0323(9)$ & $0.0009(8)$ & $-0.0017(7)$ & $0.0020(8)$ \\
\hline
\end{tabular}




\begin{tabular}{lllllll} 
C14 & $0.0426(11)$ & $0.0280(10)$ & $0.0366(10)$ & $-0.0003(9)$ & $-0.0014(8)$ & $-0.0014(8)$ \\
C15 & $0.0414(11)$ & $0.0293(9)$ & $0.0360(10)$ & $0.0020(9)$ & $-0.0005(8)$ & $0.0059(8)$ \\
C16 & $0.0438(11)$ & $0.0312(9)$ & $0.0333(9)$ & $-0.0003(9)$ & $-0.0030(8)$ & $0.0031(8)$ \\
C17 & $0.0431(11)$ & $0.0293(9)$ & $0.0354(9)$ & $0.0000(9)$ & $0.0009(8)$ & $0.0006(8)$ \\
C18 & $0.0772(17)$ & $0.0407(12)$ & $0.0377(11)$ & $0.0052(12)$ & $-0.0088(11)$ & $-0.0075(10)$ \\
\hline
\end{tabular}

Geometric parameters $\left(\AA,{ }^{\circ}\right)$

\begin{tabular}{|c|c|c|c|}
\hline $\mathrm{N} 1-\mathrm{C} 5$ & $1.336(3)$ & C6-H6A & 0.9700 \\
\hline $\mathrm{N} 1-\mathrm{C} 1$ & $1.346(3)$ & $\mathrm{C} 6-\mathrm{H} 6 \mathrm{~B}$ & 0.9700 \\
\hline $\mathrm{N} 1-\mathrm{H} 1 \mathrm{~N}$ & $0.93(5)$ & $\mathrm{C} 7-\mathrm{H} 7 \mathrm{~A}$ & 0.9700 \\
\hline $\mathrm{O} 1-\mathrm{C} 6$ & $1.423(3)$ & C7-H7B & 0.9700 \\
\hline $\mathrm{O} 1-\mathrm{H} 1 \mathrm{O}$ & $0.87(3)$ & $\mathrm{C} 8-\mathrm{H} 8 \mathrm{~A}$ & 0.9600 \\
\hline $\mathrm{O} 2-\mathrm{C} 7$ & $1.421(3)$ & $\mathrm{C} 8-\mathrm{H} 8 \mathrm{~B}$ & 0.9600 \\
\hline $\mathrm{O} 2-\mathrm{H} 2 \mathrm{O}$ & $0.92(5)$ & $\mathrm{C} 8-\mathrm{H} 8 \mathrm{C}$ & 0.9600 \\
\hline $\mathrm{O} 3-\mathrm{C} 4$ & $1.356(2)$ & $\mathrm{C} 9-\mathrm{C} 10$ & $1.488(3)$ \\
\hline $\mathrm{O} 3-\mathrm{H} 3 \mathrm{O}$ & $0.91(5)$ & $\mathrm{C} 10-\mathrm{C} 11$ & $1.330(3)$ \\
\hline $\mathrm{O} 4-\mathrm{C} 9$ & $1.253(3)$ & $\mathrm{C} 10-\mathrm{H} 10$ & 0.9300 \\
\hline $\mathrm{O} 5-\mathrm{C} 9$ & $1.267(3)$ & $\mathrm{C} 11-\mathrm{C} 12$ & $1.462(3)$ \\
\hline $\mathrm{O} 6-\mathrm{C} 15$ & $1.359(3)$ & $\mathrm{C} 11-\mathrm{H} 11$ & 0.9300 \\
\hline $\mathrm{O} 6-\mathrm{H} 6 \mathrm{O}$ & $0.94(4)$ & $\mathrm{C} 12-\mathrm{C} 17$ & $1.398(3)$ \\
\hline $\mathrm{O} 7-\mathrm{C} 14$ & $1.363(3)$ & $\mathrm{C} 12-\mathrm{C} 13$ & $1.404(3)$ \\
\hline $\mathrm{O} 7-\mathrm{C} 18$ & $1.421(3)$ & $\mathrm{C} 13-\mathrm{C} 14$ & $1.379(3)$ \\
\hline $\mathrm{O} 1 \mathrm{~W}-\mathrm{H} 1 \mathrm{~W}$ & $0.82(5)$ & $\mathrm{C} 13-\mathrm{H} 13$ & 0.9300 \\
\hline $\mathrm{O} 1 \mathrm{~W}-\mathrm{H} 2 \mathrm{~W}$ & $0.90(5)$ & $\mathrm{C} 14-\mathrm{C} 15$ & $1.405(3)$ \\
\hline $\mathrm{C} 1-\mathrm{C} 2$ & $1.374(3)$ & $\mathrm{C} 15-\mathrm{C} 16$ & $1.383(3)$ \\
\hline $\mathrm{C} 1-\mathrm{H} 1$ & 0.9300 & $\mathrm{C} 16-\mathrm{C} 17$ & $1.391(3)$ \\
\hline $\mathrm{C} 2-\mathrm{C} 3$ & $1.409(3)$ & $\mathrm{C} 16-\mathrm{H} 16$ & 0.9300 \\
\hline $\mathrm{C} 2-\mathrm{C} 6$ & $1.509(3)$ & C17-H17 & 0.9300 \\
\hline $\mathrm{C} 3-\mathrm{C} 4$ & $1.393(3)$ & C18-H18A & 0.9600 \\
\hline $\mathrm{C} 3-\mathrm{C} 7$ & $1.514(3)$ & $\mathrm{C} 18-\mathrm{H} 18 \mathrm{~B}$ & 0.9600 \\
\hline $\mathrm{C} 4-\mathrm{C} 5$ & $1.391(3)$ & $\mathrm{C} 18-\mathrm{H} 18 \mathrm{C}$ & 0.9600 \\
\hline $\mathrm{C} 5-\mathrm{C} 8$ & $1.498(3)$ & & \\
\hline $\mathrm{C} 5-\mathrm{N} 1-\mathrm{C} 1$ & $123.26(18)$ & $\mathrm{H} 8 \mathrm{~A}-\mathrm{C} 8-\mathrm{H} 8 \mathrm{~B}$ & 109.5 \\
\hline $\mathrm{C} 5-\mathrm{N} 1-\mathrm{H} 1 \mathrm{~N}$ & $118(2)$ & $\mathrm{C} 5-\mathrm{C} 8-\mathrm{H} 8 \mathrm{C}$ & 109.5 \\
\hline $\mathrm{C} 1-\mathrm{N} 1-\mathrm{H} 1 \mathrm{~N}$ & $118(2)$ & $\mathrm{H} 8 \mathrm{~A}-\mathrm{C} 8-\mathrm{H} 8 \mathrm{C}$ & 109.5 \\
\hline $\mathrm{C} 6-\mathrm{O} 1-\mathrm{H} 1 \mathrm{O}$ & $109.4(19)$ & $\mathrm{H} 8 \mathrm{~B}-\mathrm{C} 8-\mathrm{H} 8 \mathrm{C}$ & 109.5 \\
\hline $\mathrm{C} 7-\mathrm{O} 2-\mathrm{H} 2 \mathrm{O}$ & $111(3)$ & $\mathrm{O} 4-\mathrm{C} 9-\mathrm{O} 5$ & $122.47(18)$ \\
\hline $\mathrm{C} 4-\mathrm{O} 3-\mathrm{H} 3 \mathrm{O}$ & $98(3)$ & $\mathrm{O} 4-\mathrm{C} 9-\mathrm{C} 10$ & $118.83(17)$ \\
\hline $\mathrm{C} 15-\mathrm{O} 6-\mathrm{H} 6 \mathrm{O}$ & $106(3)$ & $\mathrm{O} 5-\mathrm{C} 9-\mathrm{C} 10$ & $118.69(17)$ \\
\hline $\mathrm{C} 14-\mathrm{O} 7-\mathrm{C} 18$ & $117.98(18)$ & $\mathrm{C} 11-\mathrm{C} 10-\mathrm{C} 9$ & $122.54(17)$ \\
\hline $\mathrm{H} 1 \mathrm{~W}-\mathrm{O} 1 \mathrm{~W}-\mathrm{H} 2 \mathrm{~W}$ & $102(4)$ & $\mathrm{C} 11-\mathrm{C} 10-\mathrm{H} 10$ & 118.7 \\
\hline $\mathrm{N} 1-\mathrm{C} 1-\mathrm{C} 2$ & $120.66(18)$ & $\mathrm{C} 9-\mathrm{C} 10-\mathrm{H} 10$ & 118.7 \\
\hline $\mathrm{N} 1-\mathrm{C} 1-\mathrm{H} 1$ & 119.7 & $\mathrm{C} 10-\mathrm{C} 11-\mathrm{C} 12$ & $127.11(18)$ \\
\hline $\mathrm{C} 2-\mathrm{C} 1-\mathrm{H} 1$ & 119.7 & $\mathrm{C} 10-\mathrm{C} 11-\mathrm{H} 11$ & 116.4 \\
\hline $\mathrm{C} 1-\mathrm{C} 2-\mathrm{C} 3$ & $118.51(19)$ & $\mathrm{C} 12-\mathrm{C} 11-\mathrm{H} 11$ & 116.4 \\
\hline $\mathrm{C} 1-\mathrm{C} 2-\mathrm{C} 6$ & $120.87(18)$ & $\mathrm{C} 17-\mathrm{C} 12-\mathrm{C} 13$ & $118.80(18)$ \\
\hline
\end{tabular}




\begin{tabular}{|c|c|c|c|}
\hline $\mathrm{C} 3-\mathrm{C} 2-\mathrm{C} 6$ & $120.62(18)$ & $\mathrm{C} 17-\mathrm{C} 12-\mathrm{C} 11$ & $122.46(18)$ \\
\hline $\mathrm{C} 4-\mathrm{C} 3-\mathrm{C} 2$ & $118.58(18)$ & $\mathrm{C} 13-\mathrm{C} 12-\mathrm{C} 11$ & $118.73(17)$ \\
\hline $\mathrm{C} 4-\mathrm{C} 3-\mathrm{C} 7$ & $122.45(18)$ & $\mathrm{C} 14-\mathrm{C} 13-\mathrm{C} 12$ & $120.74(18)$ \\
\hline $\mathrm{C} 2-\mathrm{C} 3-\mathrm{C} 7$ & $118.97(19)$ & $\mathrm{C} 14-\mathrm{C} 13-\mathrm{H} 13$ & 119.6 \\
\hline $\mathrm{O} 3-\mathrm{C} 4-\mathrm{C} 5$ & $115.8(2)$ & $\mathrm{C} 12-\mathrm{C} 13-\mathrm{H} 13$ & 119.6 \\
\hline $\mathrm{O} 3-\mathrm{C} 4-\mathrm{C} 3$ & $123.4(2)$ & $\mathrm{O} 7-\mathrm{C} 14-\mathrm{C} 13$ & $125.58(18)$ \\
\hline $\mathrm{C} 5-\mathrm{C} 4-\mathrm{C} 3$ & $120.81(17)$ & $\mathrm{O} 7-\mathrm{C} 14-\mathrm{C} 15$ & $114.36(18)$ \\
\hline $\mathrm{N} 1-\mathrm{C} 5-\mathrm{C} 4$ & $118.13(18)$ & $\mathrm{C} 13-\mathrm{C} 14-\mathrm{C} 15$ & $120.06(18)$ \\
\hline $\mathrm{N} 1-\mathrm{C} 5-\mathrm{C} 8$ & $118.81(19)$ & $\mathrm{O} 6-\mathrm{C} 15-\mathrm{C} 16$ & $123.92(18)$ \\
\hline $\mathrm{C} 4-\mathrm{C} 5-\mathrm{C} 8$ & $123.06(18)$ & $\mathrm{O} 6-\mathrm{C} 15-\mathrm{C} 14$ & $116.62(19)$ \\
\hline $\mathrm{O} 1-\mathrm{C} 6-\mathrm{C} 2$ & $110.78(17)$ & $\mathrm{C} 16-\mathrm{C} 15-\mathrm{C} 14$ & $119.45(18)$ \\
\hline $\mathrm{O} 1-\mathrm{C} 6-\mathrm{H} 6 \mathrm{~A}$ & 109.5 & $\mathrm{C} 15-\mathrm{C} 16-\mathrm{C} 17$ & 120.63 (19) \\
\hline $\mathrm{C} 2-\mathrm{C} 6-\mathrm{H} 6 \mathrm{~A}$ & 109.5 & $\mathrm{C} 15-\mathrm{C} 16-\mathrm{H} 16$ & 119.7 \\
\hline $\mathrm{O} 1-\mathrm{C} 6-\mathrm{H} 6 \mathrm{~B}$ & 109.5 & $\mathrm{C} 17-\mathrm{C} 16-\mathrm{H} 16$ & 119.7 \\
\hline $\mathrm{C} 2-\mathrm{C} 6-\mathrm{H} 6 \mathrm{~B}$ & 109.5 & $\mathrm{C} 16-\mathrm{C} 17-\mathrm{C} 12$ & 120.29 (19) \\
\hline $\mathrm{H} 6 \mathrm{~A}-\mathrm{C} 6-\mathrm{H} 6 \mathrm{~B}$ & 108.1 & $\mathrm{C} 16-\mathrm{C} 17-\mathrm{H} 17$ & 119.9 \\
\hline $\mathrm{O} 2-\mathrm{C} 7-\mathrm{C} 3$ & $114.4(2)$ & $\mathrm{C} 12-\mathrm{C} 17-\mathrm{H} 17$ & 119.9 \\
\hline $\mathrm{O} 2-\mathrm{C} 7-\mathrm{H} 7 \mathrm{~A}$ & 108.7 & $\mathrm{O} 7-\mathrm{C} 18-\mathrm{H} 18 \mathrm{~A}$ & 109.5 \\
\hline $\mathrm{C} 3-\mathrm{C} 7-\mathrm{H} 7 \mathrm{~A}$ & 108.7 & $\mathrm{O} 7-\mathrm{C} 18-\mathrm{H} 18 \mathrm{~B}$ & 109.5 \\
\hline $\mathrm{O} 2-\mathrm{C} 7-\mathrm{H} 7 \mathrm{~B}$ & 108.7 & $\mathrm{H} 18 \mathrm{~A}-\mathrm{C} 18-\mathrm{H} 18 \mathrm{~B}$ & 109.5 \\
\hline $\mathrm{C} 3-\mathrm{C} 7-\mathrm{H} 7 \mathrm{~B}$ & 108.7 & $\mathrm{O} 7-\mathrm{C} 18-\mathrm{H} 18 \mathrm{C}$ & 109.5 \\
\hline $\mathrm{H} 7 \mathrm{~A}-\mathrm{C} 7-\mathrm{H} 7 \mathrm{~B}$ & 107.6 & $\mathrm{H} 18 \mathrm{~A}-\mathrm{C} 18-\mathrm{H} 18 \mathrm{C}$ & 109.5 \\
\hline $\mathrm{C} 5-\mathrm{C} 8-\mathrm{H} 8 \mathrm{~A}$ & 109.5 & $\mathrm{H} 18 \mathrm{~B}-\mathrm{C} 18-\mathrm{H} 18 \mathrm{C}$ & 109.5 \\
\hline $\mathrm{C} 5-\mathrm{C} 8-\mathrm{H} 8 \mathrm{~B}$ & 109.5 & & \\
\hline
\end{tabular}

Hydrogen-bond geometry $\left(\AA,{ }^{\circ}\right)$

\begin{tabular}{|c|c|c|c|c|}
\hline$D-\mathrm{H} \cdots A$ & $D-\mathrm{H}$ & $\mathrm{H} \cdots A$ & $D \cdots A$ & $D-\mathrm{H} \cdots A$ \\
\hline $\mathrm{N} 1-\mathrm{H} 1 N \cdots \mathrm{O} 5$ & $0.93(4)$ & $1.73(5)$ & $2.641(2)$ & $166(4)$ \\
\hline $\mathrm{O} 3-\mathrm{H} 3 \mathrm{O} \cdots \mathrm{O} 2$ & $0.90(5)$ & $1.68(5)$ & $2.564(3)$ & $165(4)$ \\
\hline $\mathrm{O} 1 W-\mathrm{H} 2 W \cdots \mathrm{O} 5$ & $0.90(5)$ & $2.02(5)$ & $2.893(3)$ & $161(5)$ \\
\hline $\mathrm{C} 8-\mathrm{H} 8 A \cdots \mathrm{O} 5$ & 0.96 & 2.51 & $3.307(3)$ & 140 \\
\hline $\mathrm{O} 2-\mathrm{H} 2 O \cdots \mathrm{O} 1^{\mathrm{i}}$ & $0.91(6)$ & $1.84(6)$ & $2.747(3)$ & $171(5)$ \\
\hline $\mathrm{C} 8-\mathrm{H} 8 C \cdots \mathrm{O} 4^{\mathrm{i}}$ & 0.96 & 2.63 & $3.541(3)$ & 158 \\
\hline $\mathrm{C} 17-\mathrm{H} 17 \cdots \mathrm{O} 1 W^{\mathrm{ii}}$ & 0.93 & 2.55 & $3.472(3)$ & 167 \\
\hline $\mathrm{O} 6-\mathrm{H} 60 \cdots \mathrm{O} 4^{\mathrm{iii}}$ & $0.94(4)$ & $1.62(4)$ & $2.545(2)$ & $166(4)$ \\
\hline $\mathrm{O} 1-\mathrm{H} 1 O \cdots \mathrm{O} 1 W^{\mathrm{iv}}$ & $0.86(3)$ & $1.82(3)$ & $2.683(3)$ & $175(3)$ \\
\hline $\mathrm{O} 1 W-\mathrm{H} 1 W \cdots \mathrm{O}^{2} \mathrm{iv}^{\mathrm{iv}}$ & $0.82(5)$ & $2.12(5)$ & $2.896(2)$ & $156(4)$ \\
\hline $\mathrm{O} 1 W-\mathrm{H} 1 W \cdots \mathrm{O}^{2} \mathrm{iv}^{\mathrm{iv}}$ & $0.82(5)$ & $2.37(5)$ & $2.994(3)$ & $132(4)$ \\
\hline
\end{tabular}

Symmetry codes: (i) $x, y, z+1$; (ii) $x, y, z-1$; (iii) $-x+1, y+1 / 2,-z+1$; (iv) $-x+1, y-1 / 2,-z+2$. 